\title{
Pengaruh pemberian yogurt sinbiotik tepung pisang tanduk terhadap profil lipid tikus sindrom metabolik
}

The effect of synbiotic yogurt of tanduk banana flour in lipid profile of metabolic syndrome rats

\author{
Zana Fitriana Octavia ${ }^{1}$, Kis Djamiatun ${ }^{2}$, Nyoman Suci $^{3}$ \\ ${ }^{1}$ Program Studi Magister Ilmu Gizi, Fakultas Kedokteran Universitas Diponegoro \\ ${ }^{2}$ Bagian Biomedik, Fakultas Kedokteran Universitas Diponegoro \\ ${ }^{3}$ Bagian Patologi Klinik, Fakultas Kedokteran Universitas Diponegoro / Rumah Sakit Umum Pusat Dr. Karyadi
}

\begin{abstract}
Background: The metabolic syndrome, which is characterized by hyperglycemia, obesity, dyslipidemia, hypertension, prothrombic and proinflamatory state, is a risk factor for cardiovascular disease and diabetes mellitus. The synbiotic yogurt of tanduk banana (Musa paradisiaca fa. corniculata) flour contains lactic acid bacteria, fructooligosaccarides, flavonoids, and vitamin $C$ which all of them play role in improving the lipid profile. Objective: The aim of this study was to prove the effect of synbiotic yogurt of tanduk banana flour on lipid profile of metabolic syndrome rats. Method: This study was an true experimental with pre-post test control group design. The subject of this study were 18 metabolic syndrome male Wistar rats divided into 3 groups,i.e control group (standart diet), intervention group I (standart diet and synbiotic yogurt of banana flour 0,009 $\mathrm{ml} / \mathrm{g}$ weight/day), and intervention group II (standart diet and synbiotic yogurt of banana flour 0,018 ml/g weight/day). The intervention period was 2 weeks. Different test before and after intervention used paired t-test. The difference test between groups used One-Way ANOVA and Kruskal wallis. Results: The result showed that both of intervention group improved lipid profile significantly $(p<0,05)$. The intervention group II showed more effective improvement of lipid profile significantly $(p<0,05)$ than intervention group I. The intervention group II decreased triglycerides level 41,56\%; total cholesterol level 41,39\%; LDL-cholesterol level 57,5\%; and increased HDL-cholesterol level 139,62\%. Conclucion: The intervention of synbiotic yogurt of tanduk banana flour can decrease triglyceride level, total cholesterol level, LDL-cholesterol level, and increase HDL-cholesterol level.
\end{abstract}

KEY WORDS: lipid profile; metabolic syndrome; synbiotic; wistar rats; yogurt

\begin{abstract}
ABSTRAK
Latar belakang: Sindrom metabolik yang ditandai dengan hiperglikemia, obesitas, dislipidemia, hipertensi, keadaan protrombik, dan proinflamasi, merupakan faktor risiko penyakit jantung dan diabetes mellitus. Yogurt sinbiotik tepung pisang tanduk (Musa paradisiaca fa. corniculata) mengandung bakteri asam laktat, fruktooligosakarida, flavonoid, dan vitamin C yang berperan dalam memperbaiki profil lipid. Tujuan: Membuktikan pengaruh pemberian yogurt sinbiotik tepung pisang tanduk terhadap perbaikan profil lipid tikus sindrom metabolik. Metode: Penelitian eksperimental murni dengan rancangan pre-post test control group. Subjek yang digunakan adalah 18 ekor tikus wistar jantan sindrom metabolik yang dibagi menjadi 3 kelompok, yaitu kelompok kontrol (pakan standar); kelompok perlakuan I (pakan standar dan yogurt sinbiotik tepung pisang tanduk 0,009 ml/g BB/hari); dan kelompok perlakuan II (pakan standar dan yogurt sinbiotik tepung pisang tanduk 0,018 ml/g BB/hari). Perlakuan dilakukan selama 2 minggu. Uji beda sebelum dan setelah perlakuan menggunakan paired t-test. Uji perbedaan antarkelompok menggunakan uji One-Way ANOVA dan Kruskal Wallis. Hasil: Kedua kelompok perlakuan mengalami penurunan kadar trigliserida, kolesterol total, kolesterol LDL, dan peningkatan kadar kolesterol HDL secara signifikan $(\mathrm{p}<0,05)$. Kelompok perlakuan II menunjukkan perbaikan profil lipid yang lebih baik secara signifikan $(\mathrm{p}<0,05)$ dibandingkan kelompok perlakuan I. Kelompok perlakuan II menunjukkan penurunan kadar trigliserida 41,56\%; kadar kolesterol total 41,39\%; kadar kolesterol LDL 57,5\%; dan peningkatan kadar kolesterol HDL 139,62\%. Simpulan: Yogurt sinbiotik tepung pisang tanduk dapat menurunkan kadar trigliserida, kolesterol total, kolesterol LDL, dan meningkatkan kadar kolesterol HDL secara signifikan.
\end{abstract}

KATA KUNCI: profil lipid; sindrom metabolik; sinbiotik; tikus wistar; yogurt

Korespondensi: Zana Fitriana Octavia, Program Studi Magister Ilmu Gizi, Fakultas Kedokteran Universitas Diponegoro, Jl. Dr.Sutomo No.18 Semarang, Jawa Tengah, Indonesia, e-mail: zfoctavia@gmail.com 


\section{PENDAHULUAN}

Sindrom metabolik merupakan kelainan metabolik yang merupakan faktor risiko dari terjadinya penyakit kardiovaskular dan diabetes mellitus (DM) yang ditandai dengan hiperglikemia, obesitas, dislipidemia, hipertensi, keadaan protrombik, dan proinflamasi (1-3). Prevalensi kejadian sindrom metabolik selalu meningkat setiap tahunnya. Hal ini tidak hanya terjadi di negara maju, tetapi juga di negara berkembang. Peningkatan prevalensi sindrom metabolik sejalan dengan meningkatnya populasi obesitas, dislipidemia, hipertensi, dan DM. Berdasarkan data National Health and Nutrition Examination Survey (NHANES) III dan NHANES 1999 -2000, prevalensi sindrom metabolik di Amerika Serikat mengalami peningkatan dari 23,1\% menjadi 26,7\%. Prevalensi sindrom metabolik di Indonesia juga cukup tinggi berdasarkan penelitian sebelumnya yaitu prevalensi penduduk di Kota Jakarta yang mengalami sindrom metabolik sebanyak 28,4\% dengan komponen utama yang paling banyak ditemukan pada pria adalah hipertensi dan pada wanita adalah obesitas sentral $(4,5)$.

Pola hidup yang tidak sehat seperti asupan makanan yang tinggi kalori dan aktivitas fisik yang kurang menyebabkan meningkatnya risiko kejadian sindrom metabolik. Sebaliknya, asupan makanan yang seimbang dan aktivitas fisik yang cukup dapat mencegah risiko sindrom metabolik. Asupan makanan dapat digunakan sebagai alternatif pengganti obat dalam mengatasi sindrom metabolik. Alternatif asupan makanan yang dapat menurunkan risiko sindrom metabolik salah satunya adalah mengkonsumsi sinbiotik (6).

Sinbiotik terdiri dari prebiotik dan probiotik. Gabungan antara prebiotik dan probiotik ini memiliki efek kesehatan yang dapat mempengaruhi mikroflora yang ada pada usus. Mikroflora mempengaruhi fisiologi manusia yang berdampak pada metabolisme dan sistem imun dengan memproteksi patogen-patogen yang masuk ke dalam tubuh serta berpengaruh terhadap kesehatan saluran pencernaan. Selain terdapat mikroorganisme yang memiliki efek menguntungkan bagi tubuh dalam bentuk probiotik, di dalam sinbiotik juga terdapat prebiotik yang berfungsi sebagai substrat yang membantu meningkatkan pertumbuhan dan keaktifan satu atau lebih bakteri probiotik (7).
Produk makanan yang biasanya mengandung sinbiotik adalah yogurt yang berasal dari olahan susu yang difermentasi dengan bakteri asam laktat dan dikombinasikan dengan prebiotik berupa bahan makanan yang biasanya mengandung inulin atau fruktooligosakarida (FOS), salah satunya adalah yogurt sinbiotik tepung pisang tanduk (8). Probiotik dari yogurt diperoleh dari susu skim yang telah difermentasi dengan penambahan bakteri Streptococcus thermophylus dan Lactobacillus bulgaricus (9). Prebiotik berasal dari fruktooligosakarida (FOS) yang banyak terkandung dalam berbagai bahan makanan. Penelitian menunjukkan bahwa penambahan 1\% FOS pada yogurt dapat meningkatkan jumlah bakteri asam laktat seperti Streptococcus thermophillus, Lactobacillus acidophilus, dan Bifidobacterium sp (10).

Sumber pangan yang mengandung FOS relatif tinggi dan mudah ditemui di Indonesia adalah pisang. Kandungan dalam pisang yang dapat berperan sebagai prebiotik adalah fruktooligosakarida. Jenis pisang yang biasa digunakan untuk bahan olahan makanan adalah pisang tanduk. Pisang tanduk (Musa paradisiaca fa. corniculata) memiliki kandungan pati dan amilosa sebesar 71,73\% dan 32,99\% berat kering (11). Bahan untuk tepung pisang tanduk dibuat dari buah pisang muda atau masih mengkal agar kandungan glukosa yang ada tidak terlalu tinggi dan tidak terlalu berair. Kandungan FOS pada tepung pisang tanduk sebesar 6,08\% (12). Fruktooligosakarida yang berperan sebagai prebiotik yang memiliki efek menguntungkan terhadap mikroflora usus dengan merangsang pertumbuhan dan atau aktivitas sejumlah bakteri di usus besar dan mengurangi penyerapan lipid disertai dengan peningkatan ekskresi lipid melalui feses (13).

Beberapa penelitian menunjukkan bahwa sinbiotik yang terdiri dari probiotik dan prebiotik menunjukkan efek dalam memperbaiki profil lipid (14). Penelitian sebelumnya menunjukkan bahwa pemberian sinbiotik yang berasal dari ekstrak kedelai dan yacon yang difermentasi oleh Enterococcus faecium CRL 183 dan Lactobacillus helveticus ssp jugurti 416 bermanfaat dalam memperbaiki profil lipid pada tikus yang dikondisikan diabetes (15). Hasil penelitian di Brazil membuktikan bahwa pemberian minuman sinbiotik 
sebanyak $200 \mathrm{ml}$ selama 2 minggu pada manusia berusia 50-60 tahun dengan kolesterol total lebih dari $200 \mathrm{mg} /$ dL, kadar trigliserida lebih dari $200 \mathrm{mg} / \mathrm{dL}$, dan kadar glukosa darah lebih dari 110 mg/dL dapat meningkatkan kadar high-density lipoprotein (HDL) serta menurunkan glukosa darah (16).

Penelitian yogurt sinbiotik tepung pisang tanduk yang pengolahannya dijadikan tepung terhadap profil lipid tikus sindrom metabolik belum pernah dilakukan sebelumnya sehingga penelitian ini diawali dengan menggunakan hewan coba yaitu tikus putih jantan jenis wistar. Tikus wistar jantan dipilih sebagai subjek penelitian karena dapat memberikan hasil penelitian yang lebih stabil terhadap perlakuan yang diberikan. Berdasarkan latar belakang tersebut, peneliti berharap agar hasil penelitian ini dapat memberikan informasi yang bermanfaat bagi perkembangan ilmu pengetahuan.

\section{BAHAN DAN METODE}

Jenis penelitian ini adalah true-experimental dengan rancangan pre-post test with control group design. Penelitian dan pengumpulan data dilakukan dalam rentang waktu Desember 2016 - Januari 2017 di laboratorium Pusat Studi Pangan dan Gizi, Universitas Gajah Mada Yogyakarta. Subjek penelitian yang digunakan adalah tikus putih jenis wistar. Kriteria inklusi yang digunakan yaitu tikus jantan, usia 8-12 minggu, kondisi sehat (gerakan aktif), dan anatomi sehat serta berat badan tikus 150-200 g. Kriteria eksklusi yaitu tikus mengalami kelainan anatomi. Tikus akan dilakukan drop out apabila mengalami penurunan berat badan hingga $10 \%$, tikus sakit (mengalami diare), tikus mengalami perubahan perilaku (sakit dan kehilangan nafsu makan), dan tikus mati saat penelitian berlangsung.

Penentuan besar sampel minimal menurut World Health Organization (WHO) yaitu besar sampel setiap kelompok perlakuan minimal 5 (17). Penelitian dilakukan menggunakan 2 kelompok perlakuan dan 1 kelompok kontrol sehingga jumlah sampel keseluruhan yang dibutuhkan sebanyak 15 ekor. Sementara itu, untuk mengantisipasi adanya drop-out maka jumlah sampel setiap kelompok perlakuan ditambah menjadi 1 ekor sehingga jumlah sampel keseluruhan yang dibutuhkan sebanyak 18 ekor. Pengambilan sampel dalam tiap kelompok dilakukan secara simple randomization.

Variabel bebas dalam penelitian ini adalah pemberian yogurt sinbiotik tepung pisang tanduk dengan dosis 0,009 $\mathrm{ml} / \mathrm{g}$ berat badan (BB) tikus/hari dan 0,018 $\mathrm{ml} / \mathrm{g}$ BB tikus/hari. Variabel tergantung dalam penelitian ini adalah profil lipid (kadar trigliserida, kadar kolesterol total, kadar kolesterol LDL, dan kadar kolesterol HDL). Variabel terkontrol yaitu galur tikus, jenis kelamin tikus, umur tikus, pakan tikus, kandang tikus, dan sistem perkandangan tikus.

Tikus sebanyak 18 ekor diaklimatisasi selama 7 hari. Pakan standar yang diberikan pada semua kelompok adalah comfeed II sebanyak 20 g/200 g BB/hari dan aquadest ad libithium (18). Tahap selanjutnya adalah pemberian pakan tinggi lemak dan tinggi fruktosa selama 14 hari. Pakan tinggi lemak yang diberikan berupa minyak babi 2 ml/200 g BB tikus/hari dan kuning telur puyuh $1 \mathrm{ml} / 200 \mathrm{~g} \mathrm{BB} /$ hari sedangkan pakan tinggi fruktosa diberikan fruktosa murni sebanyak $1 \mathrm{ml} / 200$ g BB tikus/hari yang kemudian dihomogenisasi dan diberikan melalui sonde lambung (19). Sebanyak 18 ekor tikus dibagi dalam tiga kelompok, 6 ekor tikus pada kelompok kontrol diberi pakan standar; 6 ekor tikus dalam kelompok perlakuan I diberi pakan standar dan yogurt sinbiotik tepung pisang tanduk dengan dosis 0,009 ml/ $\mathrm{g}$ BB; dan 6 ekor tikus dalam kelompok perlakuan II diberi pakan standar dan yogurt sinbiotik tepung pisang tanduk dengan dosis 0,018 ml/g BB. Pemberian yogurt sinbiotik diberikan melalui sonde untuk lambung dan dilakukan satu kali sehari yaitu pada pagi hari selama 2 minggu.

Pisang tanduk yang digunakan untuk bahan pembuatan tepung adalah pisang tanduk yang mengkal (belum matang seutuhnya, 3/4 matang). Sebelum diolah, pisang dilepas dari sisirnya, dicuci, dan dikukus atau direbus selama 15 menit. Pisang yang telah matang kemudian dikupas, diiris tipis-tipis melintang atau menyerong dengan ketebalan irisan 0,25-0,75 cm kemudian direndam dalam larutan natrium metabisulfit dengan konsentrasi 0,3\% selama 10 menit. Irisan pisang tersebut ditiriskan kemudian dikeringkan menggunakan oven dengan suhu $75^{\circ} \mathrm{C}$ selama 8 jam atau sampai pisang mudah dipatahkan. Pisang yang telah kering dihaluskan dengan alat penggiling ( $g r i n d e r)$ dan diayak menggunakan 
ayakan 80 mesh.Tepung pisang tanduk kemudian diolah menjadi yogurt tepung pisang tanduk (12).

Yogurt sinbiotik tepung pisang tanduk dibuat dari susu segar tanpa lemak dan susu skim bubuk dengan menggunakan starter inokulum Lactobacillus bulgaricus dan Streptococcus thermophilus yang diperoleh dari Laboratorium Bioteknologi, Fakultas Teknologi Pertanian, Universitas Gadjah Mada dengan perbandingan 1:1 (v/v). Susu tanpa lemak segar yang digunakan untuk pembuatan yogurt adalah susu dengan tabel informasi nilai gizi mengandung 0 gram lemak. Susu skim bubuk yang digunakan adalah susu skim bubuk dengan tabel informasi nilai gizi mengandung 0 gram lemak. Proses pembuatan yogurt diawali dengan mencampurkan susu segar tanpa lemak, susu skim bubuk, dan tepung pisang. Campuran larutan tersebut dihomogenisasi kemudian dipasteurisasi pada suhu $90^{\circ} \mathrm{C}$ selama 5 menit untuk menghilangkan mikroorganisme berbahaya yang mungkin tumbuh. Setelah dipasteurisasi, campuran larutan tersebut didinginkan hingga suhu $42^{\circ} \mathrm{C}$ lalu ditambahkan inokulum Lactobacillus bulgaricus dan Streptococcus thermophilus yang telah ditumbuhkan di media susu, dengan perbandingan 1:1 (v/v). Inokulum dan campuran larutan diaduk hingga rata. Tahap selanjutnya, campuran larutan diinkubasi dalam inkubator dengan suhu $42^{\circ} \mathrm{C}$ hingga mencapai $\mathrm{pH} 4,6$. Yogurt sinbiotik yang telah jadi disimpan di lemari pendingin pada suhu $4^{\circ} \mathrm{C}(12,20)$.

Berdasarkan penelitian sebelumnya, batas aman pemberian susu fermentasi yang dianjurkan adalah $10^{6}$ $10^{9} \mathrm{cfu}$ bakteri hidup. Anjuran dosis dalam bentuk susu fermentasi untuk manusia adalah sebesar $100 \mathrm{ml}$ sehari (20). Penelitian sebelumnya menyatakan bahwa pemberian minuman sinbiotik sebanyak $200 \mathrm{ml}$ pada manusia dewasa selama 2 minggu dapat meningkatkan kadar HDL dan menurunkan glukosa darah (16). Kedua dosis tersebut kemudian dikonversikan untuk tikus sebesar $200 \mathrm{~g}$ dan hasil yang didapatkan merupakan dosis yang diperlukan untuk memperoleh dosis yogurt sinbiotik tepung pisang tanduk yang akan diberikan ke tikus yaitu sebesar 0,009 ml/g BB tikus/hari dan 0,018 ml/g BB tikus/hari.

Data yang dikumpulkan berupa berat badan tikus yang diukur setiap 1 minggu sekali dimulai dari sebelum perlakuan hingga akhir perlakuan dan hasil pemeriksaan profil lipid diukur sebanyak 3 kali yaitu setelah pemberian pakan standar (hari ke-7), setelah pemberian pakan tinggi lemak dan tinggi fruktosa (hari ke-21), dan setelah pemberian intervensi yogurt sinbiotik tepung pisang tanduk (hari ke-35). Serum darah tikus dianalisis di laboratorium Pusat Studi Pangan dan Gizi, Universitas Gajah Mada Yogyakarta. Kadar trigliserida ditentukan dengan metode Glycerol 3 Phosphate Oxidase-Phenol Amino Phenazone (GPO-PAP) sedangkan kadar kolesterol total, LDL, dan HDL ditentukan dengan metode Cholesterol OxidasePeroxidase Aminoantipyrine Phenol (CHOD-PAP).

Penelitian ini telah memperoleh ethical clearance dari Komisi Etik Penelitian Kesehatan (KEPK) Fakultas Kedokteran Universitas Diponegoro/Rumah Sakit Umum Pusat Dr. Karyadi No.047/EC/FK-RSDK/II/2017. Analisis bivariat digunakan untuk mengetahui hubungan masing-masing variabel. Data diuji normalitasnya dengan uji Saphiro-wilk. Seluruh data berdistribusi normal sehingga untuk mengetahui perbedaan profil lipid serum sebelum dan sesudah perlakuan menggunakan paired t-test. Perbedaan pengaruh dari ketiga kelompok dianalisis menggunakan uji statistik parametrik One-way ANOVA dan dilanjutkan uji Post Hoc Bonferroni untuk data terdistribusi normal. Sementara untuk distribusi data yang tidak normal dilakukan uji statistik non-parametrik Kruskal Wallis dan dilanjutkan uji Mann-Whitney.

\section{HASIL}

\section{Karakteristik hewan coba}

\section{Berat badan}

Hasil rerata berat badan tikus selama penelitian dapat dilihat pada Tabel 1. Penimbangan berat badan setiap minggu bertujuan untuk menentukan jumlah pakan standar yang diberikan kepada tikus. Pada minggu ke-1 dan ke-2, penimbangan bertujuan untuk menentukan jumlah pakan tinggi lemak dan tinggi fruktosa sedangkan pada minggu ke-3 dan ke-4 bertujuan untuk menentukan dosis yogurt sinbiotik tepung pisang tanduk. Rerata berat badan tikus mengalami peningkatan setiap tahapnya. Perbedaan rerata perubahan berat badan antarkelompok awal dan sebelum pemberian intervensi yogurt sinbiotik tepung pisang tanduk didapatkan hasil bahwa tidak terdapat perbedaan perubahan berat badan tikus antar 
Tabel 1. Rerata berat badan tikus selama penelitian

\begin{tabular}{|c|c|c|c|c|c|}
\hline \multirow{3}{*}{$\begin{array}{c}\text { Berat badan } \\
\text { (g) }\end{array}$} & \multicolumn{3}{|c|}{ Kelompok } & \multirow{3}{*}{$\begin{array}{c}\mathbf{p} \\
\text { (awal- } \\
\text { sebelum) }\end{array}$} & \multirow{3}{*}{$\begin{array}{c}p \\
\text { (sebelum- } \\
\text { sesudah) }\end{array}$} \\
\hline & Awal $(n=6)$ & Sebelum $(n=6)$ & Sesudah $(n=6)$ & & \\
\hline & Rerata \pm SB & Rerata \pm SB & Rerata \pm SB & & \\
\hline Kontrol & $186,67 \pm 5,79$ & $200,42 \pm 5,48$ & $223,08 \pm 4,99$ & \multirow{3}{*}{0,685} & \multirow{3}{*}{0,000} \\
\hline Perlakuan 1 & $185,5 \pm 6,72$ & $199,92 \pm 6,87$ & $215,08 \pm 7,19$ & & \\
\hline Perlakuan 2 & $185 \pm 10,01$ & $199,08 \pm 10,22$ & $209,50 \pm 10,55$ & & \\
\hline
\end{tabular}

Nilai p dengan uji Kruskal wallis

Tabel 2. Rerata kadar glukosa, kadar trigliserida, dan kadar kolesterol HDL setelah pemberian pakan tinggi lemak tinggi fruktosa selama 2 minggu

\begin{tabular}{lcc}
\hline Variabel & Nilai normal & Rerata \pm SD \\
\hline Glukosa (mg/dl) & $<109$ & $121,31 \pm 0,54$ \\
Trigliserida (mg/dl) & $<114$ & $145,32 \pm 3,82$ \\
Kolesterol HDL (mg/dl) & $>35$ & $25,10 \pm 1,65$ \\
\hline
\end{tabular}

kelompok $(\mathrm{p}>0,05)$ dan terdapat perbedaan perubahan rerata berat badan tikus antar kelompok sebelum dan setelah intervensi yogurt sinbiotik tepung pisang tanduk secara bermakna ( $\mathrm{p}<0,05)$. Uji dilanjutkan dengan Mann Whitney dengan hasil yang menunjukkan bahwa antara kelompok kontrol dan perlakuan I serta kelompok kontrol dan perlakuan II memiliki nilai signifikansi sebesar $\mathrm{p}=0,003$ sedangkan antara kelompok perlakuan I dan perlakuan II memiliki nilai signifikansi sebesar $\mathrm{p}=0,004$. Berdasarkan uji Mann Whitney terdapat perbedaan rerata berat badan sebelum dan setelah pemberian yogurt sinbiotik tepung pisang tanduk antar ketiga kelompok secara signifikan $(\mathrm{p}<0,05)$. Pada akhir perlakuan, rerata kenaikan berat badan tertinggi terjadi pada kelompok kontrol dan rerata terendah terjadi pada kelompok perlakuan II yang diberi yogurt sinbiotik tepung pisang dengan dosis $0,018 \mathrm{ml} / \mathrm{g}$ BB tikus.

\section{Kondisi sindrom metabolik pada tikus}

Tikus dalam penelitian ini dikondisikan mengalami sindrom metabolik dengan kriteria tikus mengalami hiperglikemia, memiliki HDL yang rendah, dan hipertrigliseridemia. Berdasarkan Tabel 2 tersebut, rerata kadar glukosa darah semua tikus sudah melebihi nilai normal dan tikus sudah mengalami hiperglikemia. Rerata kadar trigliserida darah juga sudah melebihi nilai normal dan semua tikus mengalami peningkatan kadar trigliserida sehingga semua tikus sudah mengalami hipertrigliseridemia. Penurunan kadar kolesterol HDL dialami oleh semua tikus dan rerata kadar kolesterol HDL setelah pemberian asupan tinggi lemak tinggi fruktosa sudah di bawah nilai normal. Dengan demikian, semua tikus mengalami kondisi hiperglikemia, memiliki kadar HDL yang rendah, dan hipertrigliseridemia yang merupakan kriteria sindrom metabolik.

\section{Profil lipid tikus sebelum dan setelah pakan tinggi lemak tinggi fruktosa}

Tabel 3 menunjukkan bahwa terjadi peningkatan rerata kadar trigliserida, kadar kolesterol total, dan kadar kolesterol LDL serta penurunan kadar kolesterol HDL tikus pada kelompok kontrol, kelompok perlakuan I, dan kelompok perlakuan II secara signifikan $(\mathrm{p}<0,05)$. Berdasarkan uji homogenity of varian, rerata kadar trigliserida, kolesterol total, dan kolesterol HDL memiliki varian yang sama sehingga dilanjutkan dengan uji OneWay ANOVA untuk mengetahui perbedaan perubahan profil lipid antarkelompok. Hasil analisis menggunakan uji One-Way ANOVA menunjukkan bahwa tidak terdapat perbedaan perubahan kadar kolesterol total dan kadar trigliserida tikus yang bermakna antarkelompok $(\mathrm{p}>0,05)$ serta terdapat perbedaan perubahan kadar kolesterol HDL secara bermakna antarkelompok $(\mathrm{p}<0,05)$.

Lebih lanjut, untuk mengetahui perbedaan kadar kolesterol HDL antar kelompok, maka dilanjutkan dengan uji Post Hoc Benferoni dengan hasil bahwa terdapat perbedaan bermakna antara kelompok kontrol dengan kelompok perlakuan II $(\mathrm{p}<0,05)$ dan kelompok perlakuan I dengan kelompok perlakuan II $(\mathrm{p}<0,05)$. Namun, tidak terdapat perbedaan yang bermakna antara kelompok kontrol dan kelompok perlakuan I ( $>>0,05)$. Rerata HDL kelompok perlakuan II lebih tinggi dibanding 
Tabel 3. Rerata perubahan profil lipid tikus sebelum dan setelah pemberian pakan tinggi lemak tinggi fruktosa selama 2 minggu

\begin{tabular}{|c|c|c|c|c|c|c|}
\hline \multirow{2}{*}{ Variabel } & \multirow{2}{*}{$\begin{array}{c}\text { Sebelum } \\
\text { Rerata } \pm \text { SD }\end{array}$} & \multirow{2}{*}{$\begin{array}{c}\text { Sesudah } \\
\text { Rerata } \pm \text { SD }\end{array}$} & \multirow{2}{*}{$\mathbf{p}^{1}$} & \multicolumn{2}{|c|}{$\Delta$ perubahan } & \multirow{2}{*}{$\mathbf{p}^{2}$} \\
\hline & & & & Rerata \pm SD & $\%$ & \\
\hline \multicolumn{7}{|l|}{ Trigliserida (mg/dl) } \\
\hline Kontrol & $67,64 \pm 1,55$ & $143,08 \pm 2,92$ & 0,000 & $75,45 \pm 2,54$ & 111,60 & \\
\hline Perlakuan 1 & $69,16 \pm 3,81$ & $143,08 \pm 2,92$ & 0,000 & $75,37 \pm 4,50$ & 109,50 & 0,953 \\
\hline Perlakuan 2 & $72,34 \pm 2,43$ & $148,35 \pm 4,02$ & 0,000 & $76,02 \pm 4,43$ & 105,26 & \\
\hline \multicolumn{7}{|c|}{ Kolesterol total (mg/dl) } \\
\hline Kontrol & $80,14 \pm 1,65$ & $201,58 \pm 3,59$ & 0,000 & $121,44 \pm 3,18$ & 151,59 & \\
\hline Perlakuan 1 & $81,65 \pm 4,14$ & $200,24 \pm 2,05$ & 0,000 & $118,60 \pm 4,69$ & 145,78 & 0,636 \\
\hline Perlakuan 2 & $82,00 \pm 2,44$ & $204,75 \pm 3,02$ & 0,000 & $118,60 \pm 4,69$ & 149,87 & \\
\hline \multicolumn{7}{|c|}{ Kolesterol LDL (mg/dl) } \\
\hline Kontrol & $25,81 \pm 0,92$ & $76,82 \pm 1,16$ & 0,000 & $51,00 \pm 1,66$ & 197,93 & \\
\hline Perlakuan 1 & $25,14 \pm 1,89$ & $76,82 \pm 1,16$ & 0,000 & $52,02 \pm 1,02$ & 207,97 & $0,751^{3}$ \\
\hline Perlakuan 2 & $26,94 \pm 2,17$ & $80,28 \pm 5,92$ & 0,000 & $53,34 \pm 7,01$ & 200,28 & \\
\hline \multicolumn{7}{|c|}{ Kolesterol HDL (mg/dl) } \\
\hline Kontrol & $64,70 \pm 2,41$ & $25,62 \pm 1,34$ & 0,000 & $-39,08 \pm 2,13$ & $-60,38$ & \\
\hline Perlakuan 1 & $64,17 \pm 1,91$ & $24,15, \pm 1,27$ & 0,000 & $-40,02 \pm 1,68$ & $-62,36$ & 0,001 \\
\hline Perlakuan 2 & $70,87 \pm 2,23$ & $26,87 \pm 2,31$ & 0,000 & $-44,00 \pm 1,60$ & $-64,12$ & \\
\hline
\end{tabular}

${ }^{1}$ paired t-test; ${ }^{2} \mathrm{Uji}$ One-Way ANOVA; ${ }^{3} \mathrm{Uji}$ Kruskal Wallis

kelompok lain karena sistem randomisasi sederhana yang menyebabkan hampir semua kadar HDL awal yang tinggi berada pada kelompok perlakuan II. Meskipun demikian, tidak ada selisih yang berarti karena penurunan kadar HDL kelompok kontrol sebesar 60,38\%; kelompok perlakuan I sebesar 62,36\%; dan kelompok perlakuan II sebesar $64,12 \%$. Walaupun terdapat perbedaan rerata perubahan kadar kolesterol HDL sebelum dan setelah pemberian pakan tinggi lemak dan tinggi fruktosa, semua tikus pada tahap awal memiliki kadar kolesterol HDL pada kisaran normal. Setelah pemberian pakan tinggi lemak tinggi fruktosa, semua tikus mengalami penurunan kadar kolesterol HDL hingga menjadi rendah atau di bawah rentang normal. Sementara itu, hasil uji homogenity of varian rerata kadar kolesterol LDL memiliki varian yang berbeda sehingga uji dilanjutkan dengan Kruskal Wallis dengan hasil bahwa tidak adanya perbedaan perubahan kadar kolesterol LDL tikus antarkelompok ( $\mathrm{p}>0,05)$.

\section{Profil lipid tikus sebelum dan setelah pemberian yogurt sinbiotik tepung pisang tanduk}

Pemberian yogurt pisang tanduk dilakukan selama 2 minggu. Berdasarkan Tabel 4, terjadi penurunan kadar trigliserida tikus pada pada kelompok kontrol, kelompok perlakuan I, dan kelompok perlakuan II. Penurunan kadar trigliserida pada kelompok kontrol tidak signifikan ( $>>0,05)$ sedangkan pada kelompok perlakuan I dan II terjadi penurunan yang signifikan $(\mathrm{p}<0,05)$. Penurunan kadar trigliserida yang terbesar terjadi pada kelompok perlakuan II dengan penurunan sebesar 41,56\%. Berdasarkan uji homogenity of varian, rerata kadar trigliserida memiliki varian yang sama sehingga untuk mengetahui perbedaan rerata perubahan kadar trigliserida antarkelompok dilakukan uji One-Way ANOVA dengan hasil bahwa terdapat perbedaan perubahan kadar trigliserida tikus secara bermakna antarkelompok $(\mathrm{p}<0,05)$. Dilanjutkan uji Post Hoc Benferroni dengan hasil yang menunjukkan bahwa terdapat perbedaan rerata kadar trigliserida yang bermakna antar ketiga kelompok dengan nilai signifikansi masing-masing kelompok $\mathrm{p}=0,000(\mathrm{p}<0,05)$. Pemberian yogurt sinbiotik tepung pisang tanduk dengan dosis $0,018 \mathrm{ml} / \mathrm{g}$ BB tikus/hari merupakan dosis yang paling efektif dalam menurunkan kadar trigliserida secara signifikan.

Lebih lanjut, peningkatan kadar kolesterol total tikus terjadi pada kelompok kontrol meskipun tidak signifikan ( $>>0,05)$ sedangkan pada kelompok perlakuan I dan II terjadi penurunan kadar kolesterol total secara 
signifikan $(\mathrm{p}<0,05)$. Penurunan kadar kolesterol total terbesar terjadi pada kelompok perlakuan II dengan penurunan sebesar 41,39\%. Uji One-Way ANOVA menunjukkan bahwa terdapat perbedaan perubahan kadar kolesterol total tikus secara bermakna antarkelompok $(\mathrm{p}<0,05)$. Uji dilanjutkan dengan Post Hoc Benferoni untuk mengetahui perbedaan antarkelompok dengan hasil bahwa terdapat perbedaan rerata kadar kolesterol total yang bermakna antar ketiga kelompok dengan nilai signifikasi masing-masing kelompok sebesar $\mathrm{p}=0,000$ $(\mathrm{p}<0,05)$. Dosis pemberian yogurt sinbiotik tepung pisang tanduk sebesar 0,018 ml/g BB tikus/hari merupakan dosis yang paling efektif dalam menurunkan kadar kolesterol total secara signifikan.

Demikian juga dengan rerata perubahan kadar kolesterol LDL tikus pada kelompok kontrol mengalami peningkatan yang tidak signifikan ( $>>0,05)$. Sementara pada kelompok perlakuan I dan II terjadi penurunan kadar kolesterol LDL secara signifikan $(\mathrm{p}<0,05)$. Penurunan kadar kolesterol LDL yang terbesar terjadi pada kelompok perlakuan II dengan penurunan sebesar 57,50\%. Hasil uji homogenity of varian, kadar kolesterol LDL sebelum dan setelah pemberian yogurt sinbiotik tepung pisang tanduk memiliki varian yang berbeda. Perbedaan rerata perubahan kadar kolesterol LDL antarkelompok dianalisis menggunakan uji Kruskal walis sehingga didapatkan hasil bahwa terdapat perbedaan perubahan kadar kolesterol LDL tikus secara bermakna antarkelompok $(\mathrm{p}<0,05)$. Selanjutnya, perbedaan selisih rerata kadar kolesterol LDL antarkelompok diketahui dengan uji Mann-Whitney yang menunjukkan bahwa terdapat perbedaan rerata kadar kolesterol LDL yang bermakna antar ketiga kelompok dengan nilai signifikansi masing-masing kelompok sebesar $\mathrm{p}=0,004(\mathrm{p}<0,05)$. Yogurt sinbiotik dengan dosis 0,018 ml/g BB tikus/hari merupakan dosis yang paling efektif dalam menurunkan kadar kolesterol LDL secara signifikan.

Terjadi penurunan kadar kolesterol HDL pada kelompok kontrol yang signifikan $(\mathrm{p}<0,05)$ sedangkan pada kelompok perlakuan I dan II terjadi peningkatan kadar kolesterol HDL yang signifikan $(\mathrm{p}<0,05)$. Peningkatan kadar kolesterol HDL yang terbesar terjadi pada kelompok perlakuan II dengan peningkatan sebesar 139,62\%. Hasil uji homogenity of varian menunjukkan kadar kolesterol HDL memiliki varian yang sama sehingga dianalisis menggunakan uji One Way ANOVA dengan hasil bahwa terdapat perbedaan perubahan kadar kolesterol HDL tikus secara bermakna antarkelompok $(p<0,05)$. Sementara perbedaan rerata selisih kadar kolesterol HDL sebelum dan setelah pemberian yogurt

Tabel 4. Rerata perubahan profil lipid tikus sebelum dan setelah pemberian yogurt sinbiotik tepung pisang tanduk selama 2 minggu

\begin{tabular}{|c|c|c|c|c|c|c|}
\hline \multirow{2}{*}{ Variabel } & \multirow{2}{*}{$\begin{array}{c}\text { Sebelum } \\
\text { Rerata } \pm \text { SD }\end{array}$} & \multirow{2}{*}{$\begin{array}{c}\text { Sesudah } \\
\text { Rerata } \pm \text { SD }\end{array}$} & \multirow{2}{*}{$\mathbf{p}^{1}$} & \multicolumn{2}{|c|}{$\Delta$ perubahan } & \multirow{2}{*}{$\mathbf{p}^{2}$} \\
\hline & & & & Rerata \pm SD & $\%$ & \\
\hline \multicolumn{7}{|l|}{ Trigliserida (mg/dl) } \\
\hline Kontrol & $143,08 \pm 2,92$ & $141,95 \pm 4,26$ & 0,687 & $-1,14 \pm 6,52$ & $-0,73$ & \\
\hline Perlakuan 1 & $143,08 \pm 2,92$ & $113,36 \pm 5,98$ & 0,000 & $-31,17 \pm 5,50$ & $-21,57$ & 0,000 \\
\hline Perlakuan 2 & $148,35 \pm 4,02$ & $86,64 \pm 2,71$ & 0,000 & $-61,71 \pm 5,01$ & $-41,56$ & \\
\hline \multicolumn{7}{|c|}{ Kolesterol total (mg/dl) } \\
\hline Kontrol & $201,58 \pm 3,59$ & $207,44 \pm 4,65$ & 0,081 & $5,86 \pm 6,57$ & 2,94 & \\
\hline Perlakuan 1 & $200,24 \pm 2,05$ & $146,69 \pm 7,30$ & 0,000 & $-53,55 \pm 7,99$ & $-26,73$ & 0,000 \\
\hline Perlakuan 2 & $204,75 \pm 3,02$ & $119,97 \pm 8,64$ & 0,000 & $-84,77 \pm 9,38$ & $-41,39$ & \\
\hline \multicolumn{7}{|c|}{ Kolesterol LDL (mg/dl) } \\
\hline Kontrol & $76,82 \pm 1,16$ & $77,74 \pm 1,79$ & 0,433 & $0,92 \pm 2,65$ & 1,24 & \\
\hline Perlakuan 1 & $77,16 \pm 2,22$ & $44,64 \pm 2,86$ & 0,000 & $-32,53 \pm 3,84$ & $-42,10$ & $0,001^{3}$ \\
\hline Perlakuan 2 & $80,28 \pm 5,92$ & $33,91 \pm 1,80$ & 0,000 & $-46,37 \pm 6,89$ & $-57,50$ & \\
\hline \multicolumn{7}{|c|}{ Kolesterol HDL (mg/dl) } \\
\hline Kontrol & $25,62 \pm 1,34$ & $22,43 \pm 1,37$ & 0,028 & $-2,95 \pm 2,37$ & $-11,29$ & \\
\hline Perlakuan 1 & $24,15 \pm 1,27$ & $43,51 \pm 1,83$ & 0,000 & $19,36 \pm 2,38$ & 80,64 & 0,000 \\
\hline Perlakuan 2 & $26,87 \pm 2,31$ & $60,91 \pm 2,44$ & 0,000 & $34,04 \pm 3,76$ & 139,62 & \\
\hline
\end{tabular}

${ }^{1}$ paired t-test; ${ }^{2} \mathrm{Uji}$ One-Way ANOVA; ${ }^{3} \mathrm{Uji}$ Kruskal Wallis 
sinbiotik tepung pisang tanduk antarkelompok diketahui dengan uji lanjut Post Hoc Benferoni dengan hasil bahwa terdapat perbedaan rerata kadar kolesterol HDL yang signifikan antar ketiga kelompok dengan nilai signifikansi masing-masing kelompok sebesar $\mathrm{p}=0,000(\mathrm{p}<0,05)$. Dosis yogurt sinbiotik tepung pisang tanduk sebesar 0,018 ml/grBB tikus/hari merupakan dosis yang paling efektif dalam meningkatkan kadar kolesterol HDL secara signifikan.

\section{BAHASAN}

Tikus dalam penelitian ini dikondisikan mengalami sindrom metabolik dengan pemberian pakan tinggi lemak dan tinggi fruktosa selama 2 minggu pada semua kelompok tikus. Pemberian pakan tinggi lemak dan tinggi fruktosa mengakibatkan tikus mengalami hiperglikemia dan dislipidemia. Hal ini sesuai dengan penelitian sebelumnya bahwa pemberian pakan tinggi lemak dan tinggi fruktosa dapat meningkatkan kadar trigliserida, kolesterol total, LDL, dan menurunkan HDL (22). Penelitian lainnya juga menyebutkan bahwa pemberian diet tinggi lemak dan tinggi fruktosa dapat menyebabkan dislipidemia dan hiperglikemia (23). Asupan tinggi lemak tinggi fruktosa berdampak pada metabolisme lemak dalam tubuh. Tingginya asupan lemak menyebabkan timbunan berlebih lemak di jaringan adiposa. Asupan lemak yang berlebihan dari makanan akan menyebabkan peningkatan aktivitas lipogenesis dan peningkatan produksi asam lemak bebas sehingga terjadilah mobilisasi asam lemak bebas dari jaringan lemak menuju ke hepar dan berikatan dengan gliserol membentuk trigliserida (24). Asupan tinggi fruktosa juga dapat menstimulasi lipogenesis sehingga konsumsi fruktosa dalam jumlah berlebihan akan berdampak pada peningkatan kadar trigliserida (25).

Makanan dapat juga digunakan sebagai terapi nonfarmakologi yang dapat bermanfaat dalam memperbaiki profil lipid tubuh, salah satunya adalah yogurt sinbiotik tepung pisang tanduk. Pemberian yogurt tepung pisang tanduk selama 2 minggu dapat berpengaruh dalam perbaikan profil lipid tikus. Penurunan kadar trigliserida, kolesterol total, dan kolesterol LDL serta peningkatan kolesterol HDL setelah pemberian yogurt sinbiotik terjadi secara signifikan pada kedua kelompok perlakuan dengan hasil yang tertinggi adalah pada kelompok perlakuan II.

Penelitian ini sejalan dengan penelitian- penelitian sebelumnya yang menggunakan probiotik, prebiotik maupun sinbiotik. Penelitian sebelumnya di Brazil juga menunjukkan bahwa pemberian sinbiotik yang terbuat dari kedelai dan yacon yang difermentasi dengan bakteri asam laktat terhadap tikus dapat menurunkan kadar trigliserida sebesar 33,5\% dan meningkatkan kolesterol HDL sebesar 23,7\% secara signifikan (15). Penelitian lain di Brazil juga menyebutkan bahwa pemberian minuman sinbiotik pada manusia dapat menurunkan kadar kolesterol total sebesar 25,84\%; kadar trigliserida 37,27\%; dan meningkatkan kadar kolesterol HDL 35,15\% secara signifikan (16). Penelitian yogurt sinbiotik tepung pisang tanduk ini lebih efektif dalam memperbaiki profil lipid karena dapat menurunkan kadar trigliserida sebesar 41,56\%; kadar kolesterol total 41,39\%; kadar kolesterol LDL 57,5\%; dan meningkatkan kadar kolesterol HDL $139,62 \%$.

Perbaikan profil lipid diakibatkan oleh berbagai zat yang terkandung dalam yogurt sinbiotik tepung pisang tanduk, salah satunya adalah bakteri asam laktat. Bakteri asam laktat dapat menurunkan kadar kolesterol yang diduga kemampuannya dalam mengasimilasi kolesterol dan mendekonjugasi garam empedu. Mekanisme penurunanan kadar kolesterol antara lain dipengaruhi oleh adanya bakteri asam laktat. Asimilasi kolesterol terjadi melalui mekanisme pengambilan kolesterol oleh bakteri asam laktat yang kemudian kolesterol tersebut akan berinkorporasi dengan membran sel bakteri sehingga menyebabkan berkurangnya jumlah kolesterol bebas yang ada di dalam tubuh (14). Kolesterol juga dihilangkan oleh probiotik dengan penggabungan ke membran sel selama pertumbuhan. Penggabungan kolesterol ke membran sel meningkatkan konsentrasi asam lemak jenuh dan tak jenuh, menyebabkan peningkatan kekuatan membran dan menjadi lebih tahan dari lisis (26). Bakteri asam laktat meningkatkan sekresi enzim Bile Salt Hydolase (BSH) yang merupakan enzim yang bertanggung jawab untuk dekonjugasi asam empedu pada sirkulasi enterohepatik. Hal ini akan mengakibatkan terjadinya dekonjugasi asam empedu sehingga zat tersebut menjadi sulit diabsorbsi 
kembali melalui siklus enterohepatik dan akan lebih banyak asam empedu yang diekskresikan melalui feses (27). Hal ini sesuai dengan penelitian sebelumnya yang menyebutkan bahwa pemberian probiotik bermanfaat dalam menurunkan kadar trigliserida, kolesterol total, kolesterol LDL, dan meningkatkan kolesterol HDL (28).

Tidak hanya bakteri probiotik yang dapat memperbaiki profil lipid tetapi juga prebiotik. Prebiotik yang terdapat dalam yogurt sinbiotik tepung pisang tanduk adalah FOS. Fungsi FOS dalam mengontrol lipid melalui dua mekanisme yaitu menurunkan absorbsi kolesterol yang menyebabkan peningkatan ekskresi kolesterol melalui feses dan memproduksi asam lemak rantai pendek oleh mikroflora di usus (14). Fruktooligosakarida tidak dihidrolisis oleh enzim endogen di usus halus manusia, maka ketika mencapai kolon akan dimetabolisme secara penuh oleh mikroflora melalui fermentasi, pembentukan gas (karbon dioksida, hidrogen, dan methan), dan menurunkan pH usus besar melalui produksi asam lemak rantai pendek. Fruktooligosakarida menghasilkan asam lemak rantai pendek yang sebagian besar berupa asam propionat. Propionat berfungsi sebagai inhibitor enzim lipogenik sehingga terjadi penurunan sintesis asam lemak de novo di hepar dan penurunan sintesis triasilgliserol (29,30). Hal ini sesuai dengan penelitian di Meksiko yang membuktikan bahwa fruktooligosakarida bermanfaat dalam menurunkan kadar trigliserida dan kadar kolesterol total (30).

Pisang mengandung flavonoid dan vitamin C yang dapat berperan sebagai antioksidan. Berbagai proses pengolahan dalam membuat yogurt dapat membuat kandungan vitamin $\mathrm{C}$ dan flavonoid menurun sehingga kandungan antioksidan pada yogurt sinbiotik tepung pisang mungkin tidak setinggi pada buah pisang. Kandungan senyawa antioksidan pada yogurt sinbiotik tepung pisang tanduk tidak hanya berasal dari vitamin C tetapi juga berasal dari flavonoid. Penelitian ini tidak menguji kandungan gizi yang terkandung dalam yogurt secara keseluruhan. Namun demikian, vitamin C dapat menurunkan lipid dengan meningkatkan eksresi lipid dan flavonoid dapat meningkatan kerja enzim lipoprotein lipase sehingga berpengaruh pada pebaikan lipid. Disebutkan bahwa kandungan antioksidan yang berasal dari vitamin C mempunyai efek membantu reaksi hidroksilasi dalam pembentukan asam empedu sehingga meningkatkan ekskresi lipid (31). Flavonoid berperan dalam memperbaiki profil lipid darah dengan cara meningkatkan aktivitas enzim lipoprotein lipase. Meningkatnya kerja aktivitas enzim lipoprotein lipase dapat berfungsi dalam mengendalikan kadar trigliserida. Peningkatan aktivitas enzim lipoprotein lipase mengubah very low density lipoprotein (VLDL) menjadi intermediate density lipoprotein (IDL) sehingga akumulasi VLDL di dalam hepar dapat berkurang. Aktivitas enzim lipoprotein lipase yang tinggi juga dapat menurunkan pembentukan kolesterol LDL dari IDL (32).

\section{SIMPULAN DAN SARAN}

Terjadi penurunan kadar trigliserida, kolesterol total, kolesterol LDL, dan peningkatan kolesterol HDL pada kedua kelompok perlakuan secara signifikan. Dosis yogurt sinbiotik tepung pisang tanduk yang paling efektif dalam perbaikan profil lipid sebesar 0,018 g/g BB tikus/ hari. Penelitian selanjutnya perlu dilakukan pengujian kandungan zat gizi dan fitokimia secara keseluruhan yang terdapat dalam yogurt sinbiotik tepung pisang tanduk.

\section{Pernyataan konflik kepentingan}

Penulis menyatakan tidak ada konflik kepentingan dengan pihak-pihak yang terkait dalam penelitian ini.

\section{RUJUKAN}

1. International Diabetes Federation. The IDF concencus worldwide definition of the metabolic syndrome. Journal American Medical Association 2006;213(12):1345-52.

2. Adult Treatment Panel III. Expert Panel on Detection, Evaluation, and Treatment of High Blood Cholesterol in Adults. Executive summary of the third report of the national cholesterol education program (NCEP) expert panel on detection, evaluation, and treatment of high blood cholesterol in adults (Adult Treatment Panel III). Journal American Medical Association 2001;285(16):2486-96.

3. World Health Organization. Obesity: preventing and managing the global epidemic. Geneva: WHO; 2000.

4. Ford ES, Gilles WH, Mokdad AH. Increasing prevalence of the metabolic syndrome among US adults. Diabetes Care 2004; 27:2444-9.

5. Soewondo P, Purnamasari D, Oemardi M, Soegondo S. Prevalence of Metabolic Syndrome Using NCEP/ATP III Criteria in Jakarta, Indonesia: The Jakarta Primary Non- 
communicable Disease Risk Factors Surveillance 2006. J Intern Med. 2010; 42(4): 199-203.

6. Varady KA, Jones PJH. Combination Diet and Exercise Inteventions for The Treatment of Dyslipidemia: An Effective Preliminary Strategy to Lower Cholesterol Levels. J Nutr. 2005;135:1829-35.

7. Schrezenmeir J, de Vrese M. Probiotics, Prebiotics, and Synbiotics-Approaching: A Definition. Am J Clin Nutr. 2001; 73S: 361S-4S.

8. Standar Nasional Indonesia. Yogurt. ICS 67.100.10. SNI 2981; 2009.

9. FAO/WHO: Evaluation of Health and Nutritional Properties in Food Including Powder Milk with Live Lactic Acid Bacteria. In Expert Consultation Report. Cordoba: World Health Organization of United Nations; 2011.p.1-56.

10. Gustaw W, Wiater MK, Koziol J. The Influence of Selected Prebiotics on The Growth of Lactic Acid Bacteria for BioYoghurt Production. Acta Sci Pol Technol Aliment. 2011; 10(4): 455-66.

11. Jenie BSL, Widowati S, Nurjanah S. Pengembangan Produk Tepung Pisang dengan Indeks Glikemik Rendah dan Sifat Prebiotik Sebagai Bahan Pangan Fungsional. Jurnal Teknologi dan Ilmu Pangan Institut Pertanian Bogor. 2009;1-3.

12. Karlina R, Rahayuni A. Potensi Yogurt Tanpa Lemak dengan Penambahan Tepung Pisang dan Tepung Gembili Sebagai Alternatif Menurunkan Kolesterol. Jurnal of Nutrition College. 2014; 610:1-25.

13. Costa GT, de Abreu GC, Guimarães ABB, de Vasconcelos PRL, Guimaraes SB. Fructooligosaccharide Effects on Serum Cholesterol Levels: An Overview. Acta Cirúrgica Brasileira. 2015; 30(5): 366-70.

14. Ooi LG, Liong MT. Cholesterol-Lowering Effects of Probiotics and Prebiotics: A Review of in Vivo and in Vitro Findings. Int J Mol Sci. 2010; 11: 2499-522.

15. Roselino MN, Pauly-Silveira ND, Cavallini DCU, Celiberto LS, Pinto RA, Vendramini RC, et al. A potential synbiotic product improves the lipid profile of diabetic rats. Lipids Health Dis 2012;11(114):1-9.

16. Moroti C, Magri LFS, Costa MDR, Cavalini DCU, Sivleri K. Effect of the consumption of a new symbiotic shake on glycemia and cholesterol levels in elderly people with type 2 diabetes mellitus. Lipids Health Dis 2012;11(29):1-8.

17. World Health Organization (WHO). General Guidelines for Metodologies on Research and Evaluation of Traditional Medicine. Geneva : WHO; 2001. p.1-71

18. Muflikhatur S, Murwani H. Perbedaan pengaruh antara ekstrak dan rebusan daun salam (Eugenia polyantha) dalam pencegahan peningkatan kadar kolesterol total pada tikus Sprague Dawley. Journal of Nutrition College 2014;3(1):142-9.

19. Ratnawati H, Widowati W. Anticholesterol Activity of Velvet Bean (Mucuna Pruriens L.) towards Hypercholesterolemic Rats. Sains Malaysiana. 2011; 40(4): 317-21.

20. Yuniastuti A. Pengaruh pemberian susu fermentasi Lactobacillus casei Strain Shirota terhadap perubahan kadar fraksi lipid serum tikus hiperkolesterolemia. Jurnal of Nutrition College. 2004; 1-96.

21. Nikjooy S, Hashemi S. Study the possibility of producing symbiotic yogurt containing Lactobacillus casei and wild thyme extract. International Journal of Agriculture and Crop Sciences 2015; 8(1): 61-7.

22. Ratnawati H, Widowati W. Anticholesterol Activity of Velvet Bean (Mucuna Pruriens L.) towards Hypercholesterolemic Rats. Sains Malaysiana 2011; 40(4): 317-21.

23. Crescenzo R, Bianco F, Coppola P, Mazzoli A,Tussellino $\mathrm{M}$, Carotenuto R, et al. Fructose Supplementation Worsens The Deleterious Effects of Short-Term High-Fat Feeding on Hepatic Steatosis and Lipid Metabolism in Adult Rats. Exp Physiol 2014:99(9): 1203-13.

24. Tsalissavrina I, Wahono D, Handayani D. Pengaruh Pemberian Diet Tinggi Karbohidrat dibandingkan Diet Tinggi Lemak Terhadap Kadar Trigliserida dan HDL Darah pada Rattus novergicus galur wistar. Ilmu Gizi Kesehatan Fakultas Kedokteran Universitas Brawijaya. Jurnal Kedokteran Brawijaya. 2006; 22(2): 80-9.

25. Prahastuti S. Konsumsi Fruktosa Berlebihan dapat Berdampak Buruk bagi Kesehatan Manusia. JKM 2011;10(2): 173-89.

26. Ramasamy K, Shafawi ZM, Mani V, Wan HY, Majeed ABA. Hypocholesterolaemic Effects of Probiotics. Intech. 2012; 163-80.

27. Lye HS, Rusul G, Liong MT. Removal of Cholesterol by Lactobacilli via Incorporation of and Conversion to Coprostanol. J Dairy Sci. 2010; 93: 1383-92.

28. Khamisy AESE. Effect of Bifidobacterium and Lactobacillus acidophilus in Diabetic Rats. In The 5th Arab and 2nd International: Annual Scientific Conference. Egypt: Faculty Specific Education - Mansoura University. 2010; 2425-39.

29. Scavuzzi BM, Henrique FC, Miglioranza LHS, Simão ANC, Dichi I. Impact of Prebiotics, Probiotics and Synbiotics on Components of the Metabolic Syndrome. Ann Nutr Disord \& Ther. 2014;1(2):1-13.

30. Aguilar HM, Baez DA, Estrada MJ, Guererro GM, Bautista RJH, Alarcón-Aguilar FJ, et al. Effect of fructooligosaccharides fraction from Psacalium decompositum on inflammation and dyslipidemia in rats with fructose-induced obesity. Nutrients 2014;6(2):591-604. 
31. McRae MP. Vitamin C supplementation lowers serum low-density lipoprotein cholesterol and triglycerides: a meta-analysis of 13 randomized controlled trials. Journal of Chiropractic Medicine 2008; 7: 48-58.
32. Kasolo JN, Bimenya GS, Ojok L, Ochieng J, Ogwal-Okeng JW. Phytochemicals and Uses of Moringa oleifera Leaves in Ugandan Rural Communities. Journal of Medicinal Plants Research 2010; 4(9): 753-57. 


\section{Erratum}

Octavia ZF, Djamiatun K, Suci N. Pengaruh pemberian yogurt sinbiotik tepung pisang tanduk terhadap profil lipid tikus sindrom metabolik. Jurnal Gizi Klinik Indonesia 2017;13(4):159-169.

Penulis menyadari beberapa kesalahan kecil dalam artikel yang dipublikasikan ini. Koreksi minor yang telah dibuat untuk erratum ini tidak mempengaruhi judul, abstrak, atau kesimpulan dari artikel. Koreksi minor spesifik dalam teks adalah sebagai berikut:

1) Halaman 161, kolom 2, baris 20 tertulis “...diberikan fruktosa murni sebanyak $1 \mathrm{ml} / \mathrm{g}$ BB tikus yang...” --- dosis dalam kalimat tersebut dikoreksi menjadi “...diberikan fruktosa murni sebanyak $\mathbf{1}$ ml/200 g BB tikus/hari yang...”

2) Halaman 162-163, kolom 2, baris paling bawah tertulis "Perbedaan rerata perubahan berat badan antar kelompok awal dan sebelum pemberian intervensi maupun sebelum didapatkan hasil..." ---kalimat tersebut dikoreksi menjadi "Perbedaan rerata perubahan berat badan antarkelompok pada awal dan sebelum pemberian intervensi yogurt sinbiotik tepung pisang tanduk didapatkan hasil..."

3) Halaman 162-163, kolom 1, baris 31-32 tertulis "Anjuran untuk dosis dalam bentuk susu fermentasi adalah sebesar $100 \mathrm{ml}$ sehari (21)." ---kalimat tersebut dikoreksi menjadi "Anjuran dosis dalam bentuk susu fermentasi untuk manusia adalah sebesar $100 \mathrm{ml}$ sehari (21)."

4) Halaman 163, kolom 1, baris 11 tertulis "Berdasarkan uji Post Hoc Benferoni terdapat perbedaan ..." ---kalimat tersebut dikoreksi menjadi "Berdasarkan uji Mann Whitney terdapat perbedaan ..."

5) Halaman 163, kolom 2, baris 2-3 tertulis "...trigliserida sehingga semua tikus sudah mengalami hiperglikemia" ---kalimat tersebut dikoreksi menjadi “...trigliserida sehingga semua tikus sudah mengalami hipertrigliseridemia".

6) Halaman 164, kolom 1, baris 12-14 tertulis "Setelah pemberian pakan tinggi lemak tinggi fruktosa, semua tikus mengalami penurunan hingga kadar kolesterol HDL menjadi rendah atau dibawah rentang normal". ---kalimat tersebut dikoreksi menjadi "Setelah pemberian pakan tinggi lemak tinggi fruktosa, semua tikus mengalami penurunan kadar kolesterol HDL hingga menjadi rendah atau di bawah rentang normal."

7) Halaman 164 , kolom 2 , baris 5 tertulis “...(p>0,05) sedangkan pada kelompok perlakuan I dan II terjadi penurunan yang signifikan ( $>0,05)$.” ---kalimat tersebut dikoreksi menjadi “ “..(p>0,05) sedangkan pada kelompok perlakuan I dan II terjadi penurunan yang signifikan $(\mathbf{p}<\mathbf{0 , 0 5})$."

8) Halaman 165, kolom 1, baris 1-2 tertulis “...I dan II terjadi penurunan kadar kolesterol total secara signifikan ( $>>0,05)$." ---kalimat tersebut dikoreksi menjadi “...I dan II terjadi penurunan kadar kolesterol total secara signifikan $(\mathbf{p}<\mathbf{0 , 0 5})$."

9) Halaman 165 , kolom 1 , baris 20 tertulis “... kolesterol LDL secara signifikan $(p<0,05)$.” ---kalimat tersebut dikoreksi menjadi “...kolesterol LDL secara signifikan $(\mathbf{p}<\mathbf{0 , 0 5})$."

10) Halaman 167, kolom 2, baris 17-19 pada bagian SIMPULAN DAN SARAN tertulis “...Dosis yogurt sinbiotik tepung pisang tanduk yang paling efektif dalam perbaikan profil lipid sebesar 0,018 g/ g BB tikus sindrom metabolik". ---kalimat tersebut dikoreksi menjadi "Dosis yogurt sinbiotik tepung pisang tanduk yang paling efektif dalam perbaikan profil lipid sebesar $0,018 \mathrm{~g} / \mathrm{g}$ BB tikus/ hari”.

11) Halaman 168 pada bagian daftar RUJUKAN: rujukan nomor 20 ditukar dengan nomor 21

doi: $10.22146 /$ ijen.19369 


\title{
Pengaruh pemberian yogurt sinbiotik tepung pisang tanduk terhadap profil lipid tikus sindrom metabolik
}

The effect of synbiotic yogurt of tanduk banana flour in lipid profile of metabolic syndrome rats

\author{
Zana Fitriana Octavia ${ }^{1}$, Kis Djamiatun ${ }^{2}$, Nyoman Suci ${ }^{3}$ \\ ${ }^{1}$ Program Studi Magister Ilmu Gizi, Fakultas Kedokteran Universitas Diponegoro \\ ${ }^{2}$ Bagian Biomedik, Fakultas Kedokteran Universitas Diponegoro \\ ${ }^{3}$ Bagian Patologi Klinik, Fakultas Kedokteran Universitas Diponegoro / Rumah Sakit Umum Pusat Dr. Karyadi
}

\begin{abstract}
Background: The metabolic syndrome, which is characterized by hyperglycemia, obesity, dyslipidemia, hypertension, prothrombic and proinflamatory state, is a risk factor for cardiovascular disease and diabetes mellitus. The synbiotic yogurt of tanduk banana (Musa paradisiaca fa. corniculata) flour contains lactic acid bacteria, fructooligosaccarides, flavonoids, and vitamin C which all of them play role in improving the lipid profile. Objective: The aim of this study was to prove the effect of synbiotic yogurt of tanduk banana flour on lipid profile of metabolic syndrome rats. Method: This study was an true experimental with pre-post test control group design. The subject of this study were 18 metabolic syndrome male Wistar rats divided into 3 groups, i.e control group (standart diet), intervention group I (standart diet and synbiotic yogurt of banana flour $0,009 \mathrm{ml} / \mathrm{g}$ weight/day), and intervention group II (standart diet and synbiotic yogurt of banana flour $0,018 \mathrm{ml} / \mathrm{g}$ weight/day). The intervention period was 2 weeks. Different test before and after intervention used paired t-test. The difference test between groups used One-Way ANOVA and Kruskal wallis. Results: The result showed that both of intervention group improved lipid profile significantly $(p<0,05)$. The intervention group II showed more effective improvement of lipid profile significantly $(p<0,05)$ than intervention group I. The intervention group II decreased triglycerides level 41,56\%; total cholesterol level 41,39\%; LDL-cholesterol level 57,5\%; and increased HDL-cholesterol level 139,62\%. Conclucion: The intervention of synbiotic yogurt of tanduk banana flour can decrease triglyceride level, total cholesterol level, LDL-cholesterol level, and increase HDL-cholesterol level.
\end{abstract}

KEY WORDS: lipid profile; metabolic syndrome; synbiotic; wistar rats; yogurt

\begin{abstract}
ABSTRAK
Latar belakang: Sindrom metabolik yang ditandai dengan hiperglikemia, obesitas, dislipidemia, hipertensi, keadaan protrombik, dan proinflamasi, merupakan faktor risiko penyakit jantung dan diabetes mellitus. Yogurt sinbiotik tepung pisang tanduk (Musa paradisiaca fa. corniculata) mengandung bakteri asam laktat, fruktooligosakarida, flavonoid, dan vitamin $\mathrm{C}$ yang berperan dalam memperbaiki profil lipid. Tujuan: Membuktikan pengaruh pemberian yogurt sinbiotik tepung pisang tanduk terhadap perbaikan profil lipid tikus sindrom metabolik. Metode: Penelitian eksperimental murni dengan rancangan pre-post test control group. Subjek yang digunakan adalah 18 ekor tikes wistar jantan sindrom metabolik yang dibagi menjadi 3 kelompok, yaitu kelompok kontrol (pakan standar); kelompok perlakuan I (pakan standar dan yogurt sinbiotik tepung pisang tanduk 0,009 ml/g BB/hari); dan kelompok perlakuan II (pakan standar dan yogurt sinbiotik tepung pisang tanduk $0,018 \mathrm{ml} / \mathrm{g} \mathrm{BB} /$ hari). Perlakuan dilakukan selama 2 minggu. Uji beda sebelum dan setelah perlakuan menggunakan paired t-test. Uji perbedaan antarkelompok menggunakan uji One-Way ANOVA dan Kruskal Wallis. Hasil: Kedua kelompok perlakuan mengalami penurunan kadar trigliserida, kolesterol total, kolesterol LDL, dan peningkatan kadar kolesterol HDL secara signifikan ( $<00,05)$. Kelompok perlakuan II menunjukkan perbaikan profil lipid yang lebih baik secara signifikan $(\mathrm{p}<0,05)$ dibandingkan kelompok perlakuan I. Kelompok perlakuan II menunjukkan penurunan kadar trigliserida 41,56\%; kadar kolesterol total 41,39\%; kadar kolesterol LDL 57,5\%; dan peningkatan kadar kolesterol HDL 139,62\%. Simpulan: Yogurt sinbiotik tepung pisang tanduk dapat menurunkan kadar trigliserida, kolesterol total, kolesterol LDL, dan meningkatkan kadar kolesterol HDL secara signifikan.
\end{abstract}

KATA KUNCI: profil lipid; sindrom metabolik; sinbiotik; tikus wistar; yogurt

Korespondensi: Zana Fitriana Octavia, Program Studi Magister Ilmu Gizi, Fakultas Kedokteran Universitas Diponegoro, Jl. Dr.Sutomo No.18 Semarang, Jawa Tengah, Indonesia,e-mail: zfoctavia@gmail.com 


\section{PENDAHULUAN}

Sindrom metabolik merupakan kelainan metabolik yang merupakan faktor risiko dari terjadinya penyakit kardiovaskular dan diabetes mellitus (DM) yang ditandai dengan hiperglikemia, obesitas, dislipidemia, hipertensi, keadaan protrombik, dan proinflamasi (1-3). Prevalensi kejadian sindrom metabolik selalu meningkat setiap tahunnya. Hal ini tidak hanya terjadi di negara maju, tetapi juga di negara berkembang. Peningkatan prevalensi sindrom metabolik sejalan dengan meningkatnya populasi obesitas, dislipidemia, hipertensi, dan DM. Berdasarkan data National Health and Nutrition Examination Survey (NHANES) III dan NHANES 1999 -2000, prevalensi sindrom metabolik di Amerika Serikat mengalami peningkatan dari 23,1\% menjadi 26,7\%. Prevalensi sindrom metabolik di Indonesia juga cukup tinggi berdasarkan penelitian sebelumnya yaitu prevalensi penduduk di Kota Jakarta yang mengalami sindrom metabolik sebanyak 28,4\% dengan komponen utama yang paling banyak ditemukan pada pria adalah hipertensi dan pada wanita adalah obesitas sentral $(4,5)$.

Pola hidup yang tidak sehat seperti asupan makanan yang tinggi kalori dan aktivitas fisik yang kurang menyebabkan meningkatnya risiko kejadian sindrom metabolik. Sebaliknya, asupan makanan yang seimbang dan aktivitas fisik yang cukup dapat mencegah risiko sindrom metabolik. Asupan makanan dapat digunakan sebagai alternatif pengganti obat dalam mengatasi sindrom metabolik. Alternatif asupan makanan yang dapat menurunkan risiko sindrom metabolik salah satunya adalah mengkonsumsi sinbiotik (6).

Sinbiotik terdiri dari prebiotik dan probiotik. Gabungan antara prebiotik dan probiotik ini memiliki efek kesehatan yang dapat mempengaruhi mikroflora yang ada pada usus. Mikroflora mempengaruhi fisiologi manusia yang berdampak pada metabolisme dan sistem imun dengan memproteksi patogen-patogen yang masuk ke dalam tubuh serta berpengaruh terhadap kesehatan saluran pencernaan. Selain terdapat mikroorganisme yang memiliki efek menguntungkan bagi tubuh dalam bentuk probiotik, di dalam sinbiotik juga terdapat prebiotik yang berfungsi sebagai substrat yang membantu meningkatkan pertumbuhan dan keaktifan satu atau lebih bakteri probiotik (7).
Produk makanan yang biasanya mengandung sinbiotik adalah yogurt yang berasal dari olahan susu yang difermentasi dengan bakteri asam laktat dan dikombinasikan dengan prebiotik berupa bahan makanan yang biasanya mengandung inulin atau fruktooligosakarida (FOS), salah satunya adalah yogurt sinbiotik tepung pisang tanduk (8). Probiotik dari yogurt diperoleh dari susu skim yang telah difermentasi dengan penambahan bakteri Streptococcus thermophylus dan Lactobacillus bulgaricus (9). Prebiotik berasal dari fruktooligosakarida (FOS) yang banyak terkandung dalam berbagai bahan makanan. Penelitian menunjukkan bahwa penambahan $1 \%$ FOS pada yogurt dapat meningkatkan jumlah bakteri asam laktat seperti Streptococcus thermophillus, Lactobacillus acidophilus, dan Bifidobacterium sp (10).

Sumber pangan yang mengandung FOS relatif tinggi dan mudah ditemui di Indonesia adalah pisang. Kandungan dalam pisang yang dapat berperan sebagai prebiotik adalah fruktooligosakarida. Jenis pisang yang biasa digunakan untuk bahan olahan makanan adalah pisang tanduk. Pisang tanduk (Musa paradisiaca fa. corniculata) memiliki kandungan pati dan amilosa sebesar 71,73\% dan 32,99\% berat kering (11). Bahan untuk tepung pisang tanduk dibuat dari buah pisang muda atau masih mengkal agar kandungan glukosa yang ada tidak terlalu tinggi dan tidak terlalu berair. Kandungan FOS pada tepung pisang tanduk sebesar 6,08\% (12). Fruktooligosakarida yang berperan sebagai prebiotik yang memiliki efek menguntungkan terhadap mikroflora usus dengan merangsang pertumbuhan dan atau aktivitas sejumlah bakteri di usus besar dan mengurangi penyerapan lipid disertai dengan peningkatan ekskresi lipid melalui feses (13).

Beberapa penelitian menunjukkan bahwa sinbiotik yang terdiri dari probiotik dan prebiotik menunjukkan efek dalam memperbaiki profil lipid (14). Penelitian sebelumnya menunjukkan bahwa pemberian sinbiotik yang berasal dari ekstrak kedelai dan yacon yang difermentasi oleh Enterococcus faecium CRL 183 dan Lactobacillus helveticus ssp jugurti 416 bermanfaat dalam memperbaiki profil lipid pada tikus yang dikondisikan diabetes (15). Hasil penelitian di Brazil membuktikan bahwa pemberian minuman sinbiotik 
sebanyak $200 \mathrm{ml}$ selama 2 minggu pada manusia berusia 50-60 tahun dengan kolesterol total lebih dari $200 \mathrm{mg} /$ dL, kadar trigliserida lebih dari $200 \mathrm{mg} / \mathrm{dL}$, dan kadar glukosa darah lebih dari $110 \mathrm{mg} / \mathrm{dL}$ dapat meningkatkan kadar high-density lipoprotein (HDL) serta menurunkan glukosa darah (16).

Penelitian yogurt sinbiotik tepung pisang tanduk yang pengolahannya dijadikan tepung terhadap profil lipid tikus sindrom metabolik belum pernah dilakukan sebelumnya sehingga penelitian ini diawali dengan menggunakan hewan coba yaitu tikus putih jantan jenis wistar. Tikus wistar jantan dipilih sebagai subjek penelitian karena dapat memberikan hasil penelitian yang lebih stabil terhadap perlakuan yang diberikan. Berdasarkan latar belakang tersebut, peneliti berharap agar hasil penelitian ini dapat memberikan informasi yang bermanfaat bagi perkembangan ilmu pengetahuan.

\section{BAHAN DAN METODE}

Jenis penelitian ini adalah true-experimental dengan rancangan pre-post test with control group design. Penelitian dan pengumpulan data dilakukan dalam rentang waktu Desember 2016 - Januari 2017 di laboratorium Pusat Studi Pangan dan Gizi, Universitas Gajah Mada Yogyakarta. Subjek penelitian yang digunakan adalah tikus putih jenis wistar. Kriteria inklusi yang digunakan yaitu tikus jantan, usia 8-12 minggu, kondisi sehat (gerakan aktif), dan anatomi sehat serta berat badan tikus 150-200 g. Kriteria eksklusi yaitu tikus mengalami kelainan anatomi. Tikus akan dilakukan drop out apabila mengalami penurunan berat badan hingga $10 \%$, tikus sakit (mengalami diare), tikus mengalami perubahan perilaku (sakit dan kehilangan nafsu makan), dan tikus mati saat penelitian berlangsung.

Penentuan besar sampel minimal menurut World Health Organization (WHO) yaitu besar sampel setiap kelompok perlakuan minimal 5 (17). Penelitian dilakukan menggunakan 2 kelompok perlakuan dan 1 kelompok kontrol sehingga jumlah sampel keseluruhan yang dibutuhkan sebanyak 15 ekor. Sementara itu, untuk mengantisipasi adanya drop-out maka jumlah sampel setiap kelompok perlakuan ditambah menjadi 1 ekor sehingga jumlah sampel keseluruhan yang dibutuhkan sebanyak 18 ekor. Pengambilan sampel dalam tiap kelompok dilakukan secara simple randomization.

Variabel bebas dalam penelitian ini adalah pemberian yogurt sinbiotik tepung pisang tanduk dengan dosis $0,009 \mathrm{ml} / \mathrm{g}$ berat badan (BB) tikus/hari dan 0,018 $\mathrm{ml} / \mathrm{g}$ BB tikus/hari. Variabel tergantung dalam penelitian ini adalah profil lipid (kadar trigliserida, kadar kolesterol total, kadar kolesterol LDL, dan kadar kolesterol HDL). Variabel terkontrol yaitu galur tikus, jenis kelamin tikus, umur tikus, pakan tikus, kandang tikus, dan sistem perkandangan tikus.

Tikus sebanyak 18 ekor diaklimatisasi selama 7 hari. Pakan standar yang diberikan pada semua kelompok adalah comfeed II sebanyak $20 \mathrm{~g} / 200 \mathrm{~g}$ BB/hari dan aquadest ad libithium (18). Tahap selanjutnya adalah pemberian pakan tinggi lemak dan tinggi fruktosa selama 14 hari. Pakan tinggi lemak yang diberikan berupa minyak babi $2 \mathrm{ml} / 200 \mathrm{~g}$ BB tikus/hari dan kuning telur puyuh 1 $\mathrm{ml} / 200 \mathrm{~g} \mathrm{BB} /$ hari sedangkan pakan tinggi fruktosa diberikan fruktosa murni sebanyak $1 \mathrm{ml} / \mathrm{g}$ BB tikus yang kemudian dihomogenisasi dan diberikan melalui sonde lambung (19). Sebanyak 18 ekor tikus dibagi dalam tiga kelompok, 6 ekor tikus pada kelompok kontrol diberi pakan standar; 6 ekor tikus dalam kelompok perlakuan I diberi pakan standar dan yogurt sinbiotik tepung pisang tanduk dengan dosis $0,009 \mathrm{ml} / \mathrm{g} \mathrm{BB}$; dan 6 ekor tikus dalam kelompok perlakuan II diberi pakan standar dan yogurt sinbiotik tepung pisang tanduk dengan dosis 0,018 $\mathrm{ml} / \mathrm{g}$ BB. Pemberian yogurt sinbiotik diberikan melalui sonde untuk lambung dan dilakukan satu kali sehari yaitu pada pagi hari selama 2 minggu.

Pisang tanduk yang digunakan untuk bahan pembuatan tepung adalah pisang tanduk yang mengkal (belum matang seutuhnya, 3/4 matang). Sebelum diolah, pisang dilepas dari sisirnya, dicuci, dan dikukus atau direbus selama 15 menit. Pisang yang telah matang kemudian dikupas, diiris tipis-tipis melintang atau menyerong dengan ketebalan irisan 0,25-0,75 cm kemudian direndam dalam larutan natrium metabisulfit dengan konsentrasi 0,3\% selama 10 menit. Irisan pisang tersebut ditiriskan kemudian dikeringkan menggunakan oven dengan suhu $75^{\circ} \mathrm{C}$ selama 8 jam atau sampai pisang mudah dipatahkan. Pisang yang telah kering dihaluskan dengan alat penggiling (grinder) dan diayak menggunakan 
ayakan 80 mesh. Tepung pisang tanduk kemudian diolah menjadi yogurt tepung pisang tanduk (12).

Yogurt sinbiotik tepung pisang tanduk dibuat dari susu segar tanpa lemak dan susu skim bubuk dengan menggunakan starter inokulum Lactobacillus bulgaricus dan Streptococcus thermophilus yang diperoleh dari Laboratorium Bioteknologi, Fakultas Teknologi Pertanian, Universitas Gadjah Mada dengan perbandingan 1:1 (v/v). Susu tanpa lemak segar yang digunakan untuk pembuatan yogurt adalah susu dengan tabel informasi nilai gizi mengandung 0 gram lemak. Susu skim bubuk yang digunakan adalah susu skim bubuk dengan tabel informasi nilai gizi mengandung 0 gram lemak. Proses pembuatan yogurt diawali dengan mencampurkan susu segar tanpa lemak, susu skim bubuk, dan tepung pisang. Campuran larutan tersebut dihomogenisasi kemudian dipasteurisasi pada suhu $90^{\circ} \mathrm{C}$ selama 5 menit untuk menghilangkan mikroorganisme berbahaya yang mungkin tumbuh. Setelah dipasteurisasi, campuran larutan tersebut didinginkan hingga suhu $42^{\circ} \mathrm{C}$ lalu ditambahkan inokulum Lactobacillus bulgaricus dan Streptococcus thermophilus yang telah ditumbuhkan di media susu, dengan perbandingan 1:1 (v/v). Inokulum dan campuran larutan diaduk hingga rata. Tahap selanjutnya, campuran larutan diinkubasi dalam inkubator dengan suhu $42^{\circ} \mathrm{C}$ hingga mencapai $\mathrm{pH} 4,6$. Yogurt sinbiotik yang telah jadi disimpan di lemari pendingin pada suhu $4^{\circ} \mathrm{C}(12,20)$.

Berdasarkan penelitian sebelumnya, batas aman pemberian susu fermentasi yang dianjurkan adalah $10^{6}-10^{9}$ cfu bakteri hidup. Anjuran untuk dosis dalam bentuk susu fermentasi adalah sebesar $100 \mathrm{ml}$ sehari (21). Penelitian sebelumnya menyatakan bahwa pemberian minuman sinbiotik sebanyak $200 \mathrm{ml}$ pada manusia dewasa selama 2 minggu dapat meningkatkan kadar HDL dan menurunkan glukosa darah (16). Kedua dosis tersebut kemudian dikonversikan untuk tikus sebesar $200 \mathrm{~g}$ dan hasil yang didapatkan merupakan dosis yang diperlukan untuk memperoleh dosis yogurt sinbiotik tepung pisang tanduk yang akan diberikan ke tikus yaitu sebesar 0,009 $\mathrm{ml} / \mathrm{g}$ BB tikus/hari dan 0,018 ml/g BB tikus/hari.

Data yang dikumpulkan berupa berat badan tikus yang diukur setiap 1 minggu sekali dimulai dari sebelum perlakuan hingga akhir perlakuan dan hasil pemeriksaan profil lipid diukur sebanyak 3 kali yaitu setelah pemberian pakan standar (hari ke-7), setelah pemberian pakan tinggi lemak dan tinggi fruktosa (hari ke-21), dan setelah pemberian intervensi yogurt sinbiotik tepung pisang tanduk (hari ke-35). Serum darah tikus dianalisis di laboratorium Pusat Studi Pangan dan Gizi, Universitas Gajah Mada Yogyakarta. Kadar trigliserida ditentukan dengan metode Glycerol 3 Phosphate Oxidase-Phenol Amino Phenazone (GPO-PAP) sedangkan kadar kolesterol total, LDL, dan HDL ditentukan dengan metode Cholesterol Oxidase-Peroxidase Aminoantipyrine Phenol (CHOD-PAP).

Penelitian ini telah memperoleh ethical clearance dari Komisi Etik Penelitian Kesehatan (KEPK) Fakultas Kedokteran Universitas Diponegoro/Rumah Sakit Umum Pusat Dr. Karyadi No.047/EC/FK-RSDK/II/2017. Analisis bivariat digunakan untuk mengetahui hubungan masing-masing variabel. Data diuji normalitasnya dengan uji Saphiro-wilk. Seluruh data berdistribusi normal sehingga untuk mengetahui perbedaan profil lipid serum sebelum dan sesudah perlakuan menggunakan paired t-test. Perbedaan pengaruh dari ketiga kelompok dianalisis menggunakan uji statistik parametrik One-way ANOVA dan dilanjutkan uji Post Hoc Bonferroni untuk data terdistribusi normal. Sementara untuk distribusi data yang tidak normal dilakukan uji statistik non-parametrik Kruskal Wallis dan dilanjutkan uji Mann-Whitney.

\section{HASIL}

\section{Karakteristik hewan coba}

\section{Berat badan}

Hasil rerata berat badan tikus selama penelitian dapat dilihat pada Tabel 1. Penimbangan berat badan setiap minggu bertujuan untuk menentukan jumlah pakan standar yang diberikan kepada tikus. Pada minggu ke-1 dan ke-2, penimbangan bertujuan untuk menentukan jumlah pakan tinggi lemak dan tinggi fruktosa sedangkan pada minggu ke-3 dan ke-4 bertujuan untuk menentukan dosis yogurt sinbiotik tepung pisang tanduk. Rerata berat badan tikus mengalami peningkatan setiap tahapnya. Perbedaan rerata perubahan berat badan antarkelompok awal dan sebelum pemberian intervensi maupun sebelum 
Tabel 1. Rerata berat badan tikus selama penelitian

\begin{tabular}{|c|c|c|c|c|c|}
\hline \multirow{3}{*}{$\begin{array}{c}\text { Berat badan } \\
\text { (g) }\end{array}$} & \multicolumn{3}{|c|}{ Kelompok } & \multirow{3}{*}{$\begin{array}{c}\mathbf{p} \\
\text { (awal- } \\
\text { sebelum) }\end{array}$} & \multirow{3}{*}{$\begin{array}{c}p \\
\text { (sebelum- } \\
\text { sesudah) }\end{array}$} \\
\hline & Awal $(n=6)$ & Sebelum $(n=6)$ & Sesudah $(n=6)$ & & \\
\hline & Rerata \pm SB & Rerata \pm SB & Rerata \pm SB & & \\
\hline Kontrol & $186,67 \pm 5,79$ & $200,42 \pm 5,48$ & $223,08 \pm 4,99$ & \multirow{3}{*}{0,685} & \multirow{3}{*}{0,000} \\
\hline Perlakuan 1 & $185,5 \pm 6,72$ & $199,92 \pm 6,87$ & $215,08 \pm 7,19$ & & \\
\hline Perlakuan 2 & $185 \pm 10,01$ & $199,08 \pm 10,22$ & $209,50 \pm 10,55$ & & \\
\hline
\end{tabular}

Nilai p dengan uji Kruskal wallis

Tabel 2. Rerata kadar glukosa, kadar trigliserida, dan kadar kolesterol HDL setelah pemberian pakan tinggi lemak tinggi fruktosa selama 2 minggu

\begin{tabular}{lcc}
\hline Variabel & Nilai normal & Rerata \pm SD \\
\hline Glukosa $(\mathrm{mg} / \mathrm{dl})$ & $<109$ & $121,31 \pm 0,54$ \\
Trigliserida $(\mathrm{mg} / \mathrm{dl})$ & $<114$ & $145,32 \pm 3,82$ \\
Kolesterol HDL $(\mathrm{mg} / \mathrm{dl})$ & $>35$ & $25,10 \pm 1,65$ \\
\hline
\end{tabular}

didapatkan hasil bahwa tidak terdapat perbedaan perubahan berat badan tikus antar kelompok $(p>0,05)$ dan terdapat perbedaan perubahan rerata berat badan tikus antar kelompok sebelum dan setelah intervensi secara bermakna $(\mathrm{p}<0,05)$. Uji dilanjutkan dengan Mann Whitney dengan hasil yang menunjukkan bahwa antara kelompok kontrol dan perlakuan I serta kelompok kontrol dan perlakuan II memiliki nilai signifikansi sebesar $\mathrm{p}=0,003$ sedangkan antara kelompok perlakuan I dan perlakuan II memiliki nilai signifikansi sebesar $\mathrm{p}=0,004$. Berdasarkan uji Post Hoc Benferoni terdapat perbedaan rerata berat badan sebelum dan setelah pemberian yogurt sinbiotik tepung pisang tanduk antar ketiga kelompok secara signifikan $(\mathrm{p}<0,05)$. Pada akhir perlakuan, rerata kenaikan berat badan tertinggi terjadi pada kelompok kontrol dan rerata terendah terjadi pada kelompok perlakuan II yang diberi yogurt sinbiotik tepung pisang dengan dosis $0,018 \mathrm{ml} / \mathrm{g}$ BB tikus.

\section{Kondisi sindrom metabolik pada tikus}

Tikus dalam penelitian ini dikondisikan mengalami sindrom metabolik dengan kriteria tikus mengalami hiperglikemia, memiliki HDL yang rendah, dan hipertrigliseridemia. Berdasarkan Tabel 2 tersebut, rerata kadar glukosa darah semua tikus sudah melebihi nilai normal dan tikus sudah mengalami hiperglikemia. Rerata kadar trigliserida darah juga sudah melebihi nilai normal dan semua tikus mengalami peningkatan kadar trigliserida sehingga semua tikus sudah mengalami hiperglikemia. Penurunan kadar kolesterol HDL dialami oleh semua tikus dan rerata kadar kolesterol HDL setelah pemberian asupan tinggi lemak tinggi fruktosa sudah di bawah nilai normal. Dengan demikian, semua tikus mengalami kondisi hiperglikemia, memiliki kadar HDL yang rendah, dan hipertrigliseridemia yang merupakan kriteria sindrom metabolik.

\section{Profil lipid tikus sebelum dan setelah pakan tinggi lemak tinggi fruktosa}

Tabel 3 menunjukkan bahwa terjadi peningkatan rerata kadar trigliserida, kadar kolesterol total, dan kadar kolesterol LDL serta penurunan kadar kolesterol HDL tikus pada kelompok kontrol, kelompok perlakuan I, dan kelompok perlakuan II secara signifikan $(\mathrm{p}<0,05)$. Berdasarkan uji homogenity of varian, rerata kadar trigliserida, kolesterol total, dan kolesterol HDL memiliki varian yang sama sehingga dilanjutkan dengan uji OneWay ANOVA untuk mengetahui perbedaan perubahan profil lipid antarkelompok. Hasil analisis menggunakan uji One-Way ANOVA menunjukkan bahwa tidak terdapat perbedaan perubahan kadar kolesterol total dan kadar trigliserida tikus yang bermakna antarkelompok $(p>0,05)$ serta terdapat perbedaan perubahan kadar kolesterol HDL secara bermakna antarkelompok $(\mathrm{p}<0,05)$.

Lebih lanjut, untuk mengetahui perbedaan kadar kolesterol HDL antar kelompok, maka dilanjutkan dengan uji Post Hoc Benferoni dengan hasil bahwa terdapat perbedaan bermakna antara kelompok kontrol dengan kelompok perlakuan II $(\mathrm{p}<0,05)$ dan kelompok perlakuan I dengan kelompok perlakuan II $(\mathrm{p}<0,05)$. Namun, tidak terdapat perbedaan yang bermakna antara kelompok kontrol dan kelompok perlakuan I $(p>0,05)$. 
Tabel 3. Rerata perubahan profil lipid tikus sebelum dan setelah pemberian pakan tinggi lemak tinggi fruktosa selama 2 minggu

\begin{tabular}{|c|c|c|c|c|c|c|}
\hline \multirow{2}{*}{ Variabel } & \multirow{2}{*}{$\begin{array}{c}\text { Sebelum } \\
\text { Rerata } \pm \text { SD }\end{array}$} & \multirow{2}{*}{$\begin{array}{c}\text { Sesudah } \\
\text { Rerata } \pm \text { SD }\end{array}$} & \multirow{2}{*}{$\mathbf{p}^{1}$} & \multicolumn{2}{|c|}{$\Delta$ perubahan } & \multirow{2}{*}{$\mathbf{p}^{2}$} \\
\hline & & & & Rerata \pm SD & $\%$ & \\
\hline \multicolumn{7}{|l|}{ Trigliserida (mg/dl) } \\
\hline Kontrol & $67,64 \pm 1,55$ & $143,08 \pm 2,92$ & 0,000 & $75,45 \pm 2,54$ & 111,60 & \\
\hline Perlakuan 1 & $69,16 \pm 3,81$ & $143,08 \pm 2,92$ & 0,000 & $75,37 \pm 4,50$ & 109,50 & 0,953 \\
\hline Perlakuan 2 & $72,34 \pm 2,43$ & $148,35 \pm 4,02$ & 0,000 & $76,02 \pm 4,43$ & 105,26 & \\
\hline \multicolumn{7}{|c|}{ Kolesterol total (mg/dl) } \\
\hline Kontrol & $80,14 \pm 1,65$ & $201,58 \pm 3,59$ & 0,000 & $121,44 \pm 3,18$ & 151,59 & \\
\hline Perlakuan 1 & $81,65 \pm 4,14$ & $200,24 \pm 2,05$ & 0,000 & $118,60 \pm 4,69$ & 145,78 & 0,636 \\
\hline Perlakuan 2 & $82,00 \pm 2,44$ & $204,75 \pm 3,02$ & 0,000 & $118,60 \pm 4,69$ & 149,87 & \\
\hline \multicolumn{7}{|c|}{ Kolesterol LDL (mg/dl) } \\
\hline Kontrol & $25,81 \pm 0,92$ & $76,82 \pm 1,16$ & 0,000 & $51,00 \pm 1,66$ & 197,93 & \\
\hline Perlakuan 1 & $25,14 \pm 1,89$ & $76,82 \pm 1,16$ & 0,000 & $52,02 \pm 1,02$ & 207,97 & $0,751^{3}$ \\
\hline Perlakuan 2 & $26,94 \pm 2,17$ & $80,28 \pm 5,92$ & 0,000 & $53,34 \pm 7,01$ & 200,28 & \\
\hline \multicolumn{7}{|c|}{ Kolesterol HDL (mg/dl) } \\
\hline Kontrol & $64,70 \pm 2,41$ & $25,62 \pm 1,34$ & 0,000 & $-39,08 \pm 2,13$ & $-60,38$ & \\
\hline Perlakuan 1 & $64,17 \pm 1,91$ & $24,15, \pm 1,27$ & 0,000 & $-40,02 \pm 1,68$ & $-62,36$ & 0,001 \\
\hline Perlakuan 2 & $70,87 \pm 2,23$ & $26,87 \pm 2,31$ & 0,000 & $-44,00 \pm 1,60$ & $-64,12$ & \\
\hline
\end{tabular}

${ }^{1}$ paired $t$-test; ${ }^{2} \mathrm{Uji}$ One-Way ANOVA; ${ }^{3} \mathrm{Uji}$ Kruskal Wallis

Rerata HDL kelompok perlakuan II lebih tinggi dibanding kelompok lain karena sistem randomisasi sederhana yang menyebabkan hampir semua kadar HDL awal yang tinggi berada pada kelompok perlakuan II. Meskipun demikian, tidak ada selisih yang berarti karena penurunan kadar HDL kelompok kontrol sebesar 60,38\%; kelompok perlakuan I sebesar 62,36\%; dan kelompok perlakuan II sebesar $64,12 \%$. Walaupun terdapat perbedaan rerata perubahan kadar kolesterol HDL sebelum dan setelah pemberian pakan tinggi lemak dan tinggi fruktosa, semua tikus pada tahap awal memiliki kadar kolesterol HDL pada kisaran normal. Setelah pemberian pakan tinggi lemak tinggi fruktosa, semua tikus mengalami penurunan hingga kadar kolesterol HDL menjadi rendah atau di bawah rentang normal. Sementara itu, hasil uji homogenity of varian rerata kadar kolesterol LDL memiliki varian yang berbeda sehingga uji dilanjutkan dengan Kruskal Wallis dengan hasil bahwa tidak adanya perbedaan perubahan kadar kolesterol LDL tikus antarkelompok $(\mathrm{p}>0,05)$.

\section{Profil lipid tikus sebelum dan setelah pemberian yogurt sinbiotik tepung pisang tanduk}

Pemberian yogurt pisang tanduk dilakukan selama 2 minggu. Berdasarkan Tabel 4, terjadi penurunan kadar trigliserida tikus pada pada kelompok kontrol, kelompok perlakuan I, dan kelompok perlakuan II. Penurunan kadar trigliserida pada kelompok kontrol tidak signifikan ( $p>0,05)$ sedangkan pada kelompok perlakuan I dan II terjadi penurunan yang signifikan $(\mathrm{p}>0,05)$. Penurunan kadar trigliserida yang terbesar terjadi pada kelompok perlakuan II dengan penurunan sebesar $41,56 \%$. Berdasarkan uji homogenity of varian, rerata kadar trigliserida memiliki varian yang sama sehingga untuk mengetahui perbedaan rerata perubahan kadar trigliserida antarkelompok dilakukan uji One-Way ANOVA dengan hasil bahwa terdapat perbedaan perubahan kadar trigliserida tikus secara bermakna antarkelompok ( $<<0,05)$. Dilanjutkan uji Post Hoc Benferroni dengan hasil yang menunjukkan bahwa terdapat perbedaan rerata kadar trigliserida yang bermakna antar ketiga kelompok dengan nilai signifikansi masing-masing kelompok $\mathrm{p}=0,000(\mathrm{p}<0,05)$. Pemberian yogurt sinbiotik tepung pisang tanduk dengan dosis $0,018 \mathrm{ml} / \mathrm{g}$ BB tikus/hari merupakan dosis yang paling efektif dalam menurunkan kadar trigliserida secara signifikan.

Lebih lanjut, peningkatan kadar kolesterol total tikus terjadi pada kelompok kontrol meskipun tidak signifikan $(\mathrm{p}>0,05)$ sedangkan pada kelompok perlakuan 
I dan II terjadi penurunan kadar kolesterol total secara signifikan $(\mathrm{p}>0,05)$. Penurunan kadar kolesterol total terbesar terjadi pada kelompok perlakuan II dengan penurunan sebesar 41,39\%. Uji One-Way ANOVA menunjukkan bahwa terdapat perbedaan perubahan kadar kolesterol total tikus secara bermakna antarkelompok $(\mathrm{p}<0,05)$. Uji dilanjutkan dengan Post Hoc Benferoni untuk mengetahui perbedaan antarkelompok dengan hasil bahwa terdapat perbedaan rerata kadar kolesterol total yang bermakna antar ketiga kelompok dengan nilai signifikasi masing-masing kelompok sebesar $p=0,000$ $(\mathrm{p}<0,05)$. Dosis pemberian yogurt sinbiotik tepung pisang tanduk sebesar 0,018 ml/g BB tikus/hari merupakan dosis yang paling efektif dalam menurunkan kadar kolesterol total secara signifikan.

Demikian juga dengan rerata perubahan kadar kolesterol LDL tikus pada kelompok kontrol mengalami peningkatan yang tidak signifikan $(p>0,05)$. Sementara pada kelompok perlakuan I dan II terjadi penurunan kadar kolesterol LDL secara signifikan $(\mathrm{p}>0,05)$. Penurunan kadar kolesterol LDL yang terbesar terjadi pada kelompok perlakuan II dengan penurunan sebesar 57,50\%. Hasil uji homogenity of varian, kadar kolesterol LDL sebelum dan setelah pemberian yogurt sinbiotik tepung pisang tanduk memiliki varian yang berbeda. Perbedaan rerata perubahan kadar kolesterol LDL antarkelompok dianalisis menggunakan uji Kruskal walis sehingga didapatkan hasil bahwa terdapat perbedaan perubahan kadar kolesterol LDL tikus secara bermakna antarkelompok $(p<0,05)$. Selanjutnya, perbedaan selisih rerata kadar kolesterol LDL antarkelompok diketahui dengan uji Mann-Whitney yang menunjukkan bahwa terdapat perbedaan rerata kadar kolesterol LDL yang bermakna antar ketiga kelompok dengan nilai signifikansi masing-masing kelompok sebesar $\mathrm{p}=0,004(\mathrm{p}<0,05)$. Yogurt sinbiotik dengan dosis $0,018 \mathrm{ml} / \mathrm{g}$ BB tikus/hari merupakan dosis yang paling efektif dalam menurunkan kadar kolesterol LDL secara signifikan.

Terjadi penurunan kadar kolesterol HDL pada kelompok kontrol yang signifikan $(\mathrm{p}<0,05)$ sedangkan pada kelompok perlakuan I dan II terjadi peningkatan kadar kolesterol HDL yang signifikan $(p<0,05)$. Peningkatan kadar kolesterol HDL yang terbesar terjadi pada kelompok perlakuan II dengan peningkatan sebesar $139,62 \%$. Hasil uji homogenity of varian menunjukkan kadar kolesterol HDL memiliki varian yang sama sehingga dianalisis menggunakan uji One Way ANOVA dengan hasil bahwa terdapat perbedaan perubahan kadar kolesterol HDL tikus secara bermakna antarkelompok $(p<0,05)$. Sementara perbedaan rerata selisih kadar

Tabel 4. Rerata perubahan profil lipid tikus sebelum dan setelah pemberian yogurt sinbiotik tepung pisang tanduk selama 2 minggu

\begin{tabular}{|c|c|c|c|c|c|c|}
\hline \multirow{2}{*}{ Variabel } & \multirow{2}{*}{$\begin{array}{c}\text { Sebelum } \\
\text { Rerata } \pm \text { SD } \\
\end{array}$} & \multirow{2}{*}{$\begin{array}{c}\text { Sesudah } \\
\text { Rerata } \pm \text { SD }\end{array}$} & \multirow{2}{*}{$\mathbf{p}^{1}$} & \multicolumn{2}{|c|}{$\Delta$ perubahan } & \multirow{2}{*}{$\mathbf{p}^{2}$} \\
\hline & & & & Rerata \pm SD & $\%$ & \\
\hline \multicolumn{7}{|l|}{ Trigliserida (mg/dl) } \\
\hline Kontrol & $143,08 \pm 2,92$ & $141,95 \pm 4,26$ & 0,687 & $-1,14 \pm 6,52$ & $-0,73$ & \\
\hline Perlakuan 1 & $143,08 \pm 2,92$ & $113,36 \pm 5,98$ & 0,000 & $-31,17 \pm 5,50$ & $-21,57$ & 0,000 \\
\hline Perlakuan 2 & $148,35 \pm 4,02$ & $86,64 \pm 2,71$ & 0,000 & $-61,71 \pm 5,01$ & $-41,56$ & \\
\hline \multicolumn{7}{|c|}{ Kolesterol total (mg/dl) } \\
\hline Kontrol & $201,58 \pm 3,59$ & $207,44 \pm 4,65$ & 0,081 & $5,86 \pm 6,57$ & 2,94 & \\
\hline Perlakuan 1 & $200,24 \pm 2,05$ & $146,69 \pm 7,30$ & 0,000 & $-53,55 \pm 7,99$ & $-26,73$ & 0,000 \\
\hline Perlakuan 2 & $204,75 \pm 3,02$ & $119,97 \pm 8,64$ & 0,000 & $-84,77 \pm 9,38$ & $-41,39$ & \\
\hline \multicolumn{7}{|c|}{ Kolesterol LDL (mg/dl) } \\
\hline Kontrol & $76,82 \pm 1,16$ & $77,74 \pm 1,79$ & 0,433 & $0,92 \pm 2,65$ & 1,24 & \\
\hline Perlakuan 1 & $77,16 \pm 2,22$ & $44,64 \pm 2,86$ & 0,000 & $-32,53 \pm 3,84$ & $-42,10$ & 0,001 \\
\hline Perlakuan 2 & $80,28 \pm 5,92$ & $33,91 \pm 1,80$ & 0,000 & $-46,37 \pm 6,89$ & $-57,50$ & \\
\hline \multicolumn{7}{|c|}{ Kolesterol HDL (mg/dl) } \\
\hline Kontrol & $25,62 \pm 1,34$ & $22,43 \pm 1,37$ & 0,028 & $-2,95 \pm 2,37$ & $-11,29$ & \\
\hline Perlakuan 1 & $24,15 \pm 1,27$ & $43,51 \pm 1,83$ & 0,000 & $19,36 \pm 2,38$ & 80,64 & 0,000 \\
\hline Perlakuan 2 & $26,87 \pm 2,31$ & $60,91 \pm 2,44$ & 0,000 & $34,04 \pm 3,76$ & 139,62 & \\
\hline
\end{tabular}

${ }^{1}$ paired $t$-test; ${ }^{2} \mathrm{Uji}$ One-Way ANOVA; ${ }^{3} \mathrm{Uji}$ Kruskal Wallis 
kolesterol HDL sebelum dan setelah pemberian yogurt sinbiotik tepung pisang tanduk antarkelompok diketahui dengan uji lanjut Post Hoc Benferoni dengan hasil bahwa terdapat perbedaan rerata kadar kolesterol HDL yang signifikan antar ketiga kelompok dengan nilai signifikansi masing-masing kelompok sebesar $\mathrm{p}=0,000(\mathrm{p}<0,05)$. Dosis yogurt sinbiotik tepung pisang tanduk sebesar 0,018 $\mathrm{ml} / \mathrm{grBB}$ tikus/hari merupakan dosis yang paling efektif dalam meningkatkan kadar kolesterol HDL secara signifikan.

\section{BAHASAN}

Tikus dalam penelitian ini dikondisikan mengalami sindrom metabolik dengan pemberian pakan tinggi lemak dan tinggi fruktosa selama 2 minggu pada semua kelompok tikus. Pemberian pakan tinggi lemak dan tinggi fruktosa mengakibatkan tikus mengalami hiperglikemia dan dislipidemia. Hal ini sesuai dengan penelitian sebelumnya bahwa pemberian pakan tinggi lemak dan tinggi fruktosa dapat meningkatkan kadar trigliserida, kolesterol total, LDL, dan menurunkan HDL (22). Penelitian lainnya juga menyebutkan bahwa pemberian diet tinggi lemak dan tinggi fruktosa dapat menyebabkan dislipidemia dan hiperglikemia (23). Asupan tinggi lemak tinggi fruktosa berdampak pada metabolisme lemak dalam tubuh. Tingginya asupan lemak menyebabkan timbunan berlebih lemak di jaringan adiposa. Asupan lemak yang berlebihan dari makanan akan menyebabkan peningkatan aktivitas lipogenesis dan peningkatan produksi asam lemak bebas sehingga terjadilah mobilisasi asam lemak bebas dari jaringan lemak menuju ke hepar dan berikatan dengan gliserol membentuk trigliserida (24). Asupan tinggi fruktosa juga dapat menstimulasi lipogenesis sehingga konsumsi fruktosa dalam jumlah berlebihan akan berdampak pada peningkatan kadar trigliserida (25).

Makanan dapat juga digunakan sebagai terapi nonfarmakologi yang dapat bermanfaat dalam memperbaiki profil lipid tubuh, salah satunya adalah yogurt sinbiotik tepung pisang tanduk. Pemberian yogurt tepung pisang tanduk selama 2 minggu dapat berpengaruh dalam perbaikan profil lipid tikus. Penurunan kadar trigliserida, kolesterol total, dan kolesterol LDL serta peningkatan kolesterol HDL setelah pemberian yogurt sinbiotik terjadi secara signifikan pada kedua kelompok perlakuan dengan hasil yang tertinggi adalah pada kelompok perlakuan II.

Penelitian ini sejalan dengan penelitian- penelitian sebelumnya yang menggunakan probiotik, prebiotik maupun sinbiotik. Penelitian sebelumnya di Brazil juga menunjukkan bahwa pemberian sinbiotik yang terbuat dari kedelai dan yacon yang difermentasi dengan bakteri asam laktat terhadap tikus dapat menurunkan kadar trigliserida sebesar 33,5\% dan meningkatkan kolesterol HDL sebesar 23,7\% secara signifikan (15). Penelitian lain di Brazil juga menyebutkan bahwa pemberian minuman sinbiotik pada manusia dapat menurunkan kadar kolesterol total sebesar 25,84\%; kadar trigliserida 37,27\%; dan meningkatkan kadar kolesterol HDL 35,15\% secara signifikan (16). Penelitian yogurt sinbiotik tepung pisang tanduk ini lebih efektif dalam memperbaiki profil lipid karena dapat menurunkan kadar trigliserida sebesar 41,56\%; kadar kolesterol total 41,39\%; kadar kolesterol LDL 57,5\%; dan meningkatkan kadar kolesterol HDL $139,62 \%$.

Perbaikan profil lipid diakibatkan oleh berbagai zat yang terkandung dalam yogurt sinbiotik tepung pisang tanduk, salah satunya adalah bakteri asam laktat. Bakteri asam laktat dapat menurunkan kadar kolesterol yang diduga kemampuannya dalam mengasimilasi kolesterol dan mendekonjugasi garam empedu. Mekanisme penurunanan kadar kolesterol antara lain dipengaruhi oleh adanya bakteri asam laktat. Asimilasi kolesterol terjadi melalui mekanisme pengambilan kolesterol oleh bakteri asam laktat yang kemudian kolesterol tersebut akan berinkorporasi dengan membran sel bakteri sehingga menyebabkan berkurangnya jumlah kolesterol bebas yang ada di dalam tubuh (14). Kolesterol juga dihilangkan oleh probiotik dengan penggabungan ke membran sel selama pertumbuhan. Penggabungan kolesterol ke membran sel meningkatkan konsentrasi asam lemak jenuh dan tak jenuh, menyebabkan peningkatan kekuatan membran dan menjadi lebih tahan dari lisis (26). Bakteri asam laktat meningkatkan sekresi enzim Bile Salt Hydolase (BSH) yang merupakan enzim yang bertanggung jawab untuk dekonjugasi asam empedu pada sirkulasi enterohepatik. Hal ini akan mengakibatkan terjadinya dekonjugasi asam 
empedu sehingga zat tersebut menjadi sulit diabsorbsi kembali melalui siklus enterohepatik dan akan lebih banyak asam empedu yang diekskresikan melalui feses (27). Hal ini sesuai dengan penelitian sebelumnya yang menyebutkan bahwa pemberian probiotik bermanfaat dalam menurunkan kadar trigliserida, kolesterol total, kolesterol LDL, dan meningkatkan kolesterol HDL (28).

Tidak hanya bakteri probiotik yang dapat memperbaiki profil lipid tetapi juga prebiotik. Prebiotik yang terdapat dalam yogurt sinbiotik tepung pisang tanduk adalah FOS. Fungsi FOS dalam mengontrol lipid melalui dua mekanisme yaitu menurunkan absorbsi kolesterol yang menyebabkan peningkatan ekskresi kolesterol melalui feses dan memproduksi asam lemak rantai pendek oleh mikroflora di usus (14). Fruktooligosakarida tidak dihidrolisis oleh enzim endogen di usus halus manusia, maka ketika mencapai kolon akan dimetabolisme secara penuh oleh mikroflora melalui fermentasi, pembentukan gas (karbon dioksida, hidrogen, dan methan), dan menurunkan $\mathrm{pH}$ usus besar melalui produksi asam lemak rantai pendek. Fruktooligosakarida menghasilkan asam lemak rantai pendek yang sebagian besar berupa asam propionat. Propionat berfungsi sebagai inhibitor enzim lipogenik sehingga terjadi penurunan sintesis asam lemak de novo di hepar dan penurunan sintesis triasilgliserol $(29,30)$. Hal ini sesuai dengan penelitian di Meksiko yang membuktikan bahwa fruktooligosakarida bermanfaat dalam menurunkan kadar trigliserida dan kadar kolesterol total (30).

Pisang mengandung flavonoid dan vitamin $\mathrm{C}$ yang dapat berperan sebagai antioksidan. Berbagai proses pengolahan dalam membuat yogurt dapat membuat kandungan vitamin $\mathrm{C}$ dan flavonoid menurun sehingga kandungan antioksidan pada yogurt sinbiotik tepung pisang mungkin tidak setinggi pada buah pisang. Kandungan senyawa antioksidan pada yogurt sinbiotik tepung pisang tanduk tidak hanya berasal dari vitamin C tetapi juga berasal dari flavonoid. Penelitian ini tidak menguji kandungan gizi yang terkandung dalam yogurt secara keseluruhan. Namun demikian, vitamin C dapat menurunkan lipid dengan meningkatkan eksresi lipid dan flavonoid dapat meningkatan kerja enzim lipoprotein lipase sehingga berpengaruh pada pebaikan lipid. Disebutkan bahwa kandungan antioksidan yang berasal dari vitamin $\mathrm{C}$ mempunyai efek membantu reaksi hidroksilasi dalam pembentukan asam empedu sehingga meningkatkan ekskresi lipid (31). Flavonoid berperan dalam memperbaiki profil lipid darah dengan cara meningkatkan aktivitas enzim lipoprotein lipase. Meningkatnya kerja aktivitas enzim lipoprotein lipase dapat berfungsi dalam mengendalikan kadar trigliserida. Peningkatan aktivitas enzim lipoprotein lipase mengubah very low density lipoprotein (VLDL) menjadi intermediate density lipoprotein (IDL) sehingga akumulasi VLDL di dalam hepar dapat berkurang. Aktivitas enzim lipoprotein lipase yang tinggi juga dapat menurunkan pembentukan kolesterol LDL dari IDL (32).

\section{SIMPULAN DAN SARAN}

Terjadi penurunan kadar trigliserida, kolesterol total, kolesterol LDL, dan peningkatan kolesterol HDL pada kedua kelompok perlakuan secara signifikan. Dosis yogurt sinbiotik tepung pisang tanduk yang paling efektif dalam perbaikan profil lipid sebesar $0,018 \mathrm{~g} / \mathrm{g}$ BB tikus sindrom metabolik. Penelitian selanjutnya perlu dilakukan pengujian kandungan zat gizi dan fitokimia secara keseluruhan yang terdapat dalam yogurt sinbiotik tepung pisang tanduk.

\section{Pernyataan konflik kepentingan}

Penulis menyatakan tidak ada konflik kepentingan dengan pihak-pihak yang terkait dalam penelitian ini.

\section{RUJUKAN}

1. International Diabetes Federation. The IDF concencus worldwide definition of the metabolic syndrome. Journal American Medical Association 2006;213(12):1345-52.

2. Adult Treatment Panel III. Expert Panel on Detection, Evaluation, and Treatment of High Blood Cholesterol in Adults. Executive summary of the third report of the national cholesterol education program (NCEP) expert panel on detection, evaluation, and treatment of high blood cholesterol in adults (Adult Treatment Panel III). Journal American Medical Association 2001;285(16):2486-96.

3. World Health Organization. Obesity: preventing and managing the global epidemic. Geneva: WHO; 2000.

4. Ford ES, Gilles WH, Mokdad AH. Increasing prevalence of the metabolic syndrome among US adults. Diabetes Care 2004; 27:2444-9. 
5. Soewondo P, Purnamasari D, Oemardi M, Soegondo S. Prevalence of Metabolic Syndrome Using NCEP/ATP III Criteria in Jakarta, Indonesia: The Jakarta Primary Noncommunicable Disease Risk Factors Surveillance 2006. J Intern Med. 2010; 42(4): 199-203.

6. Varady KA, Jones PJH. Combination Diet and Exercise Inteventions for The Treatment of Dyslipidemia: An Effective Preliminary Strategy to Lower Cholesterol Levels. J Nutr. 2005;135:1829-35.

7. Schrezenmeir J, de Vrese M. Probiotics, Prebiotics, and Synbiotics-Approaching: A Definition. Am J Clin Nutr. 2001; 73S: 361S-4S.

8. Standar Nasional Indonesia. Yogurt. ICS 67.100.10. SNI 2981; 2009.

9. FAO/WHO: Evaluation of Health and Nutritional Properties in Food Including Powder Milk with Live Lactic Acid Bacteria. In Expert Consultation Report. Cordoba: World Health Organization of United Nations; 2011.p.1-56.

10. Gustaw W, Wiater MK, Koziol J. The Influence of Selected Prebiotics on The Growth of Lactic Acid Bacteria for BioYoghurt Production. Acta Sci Pol Technol Aliment. 2011; 10(4): 455-66.

11. Jenie BSL, Widowati S, Nurjanah S. Pengembangan Produk Tepung Pisang dengan Indeks Glikemik Rendah dan Sifat Prebiotik Sebagai Bahan Pangan Fungsional. Jurnal Teknologi dan Ilmu Pangan Institut Pertanian Bogor. 2009;1-3.

12. Karlina R, Rahayuni A. Potensi Yogurt Tanpa Lemak dengan Penambahan Tepung Pisang dan Tepung Gembili Sebagai Alternatif Menurunkan Kolesterol. Jurnal of Nutrition College. 2014; 610:1-25.

13. Costa GT, de Abreu GC, Guimarães ABB, de Vasconcelos PRL, Guimaraes SB. Fructooligosaccharide Effects on Serum Cholesterol Levels: An Overview. Acta Cirúrgica Brasileira. 2015; 30(5): 366-70.

14. Ooi LG, Liong MT. Cholesterol-Lowering Effects of Probiotics and Prebiotics: A Review of in Vivo and in Vitro Findings. Int J Mol Sci. 2010; 11: 2499-522.

15. Roselino MN, Pauly-Silveira ND, Cavallini DCU, Celiberto LS, Pinto RA, Vendramini RC, et al. A potential synbiotic product improves the lipid profile of diabetic rats. Lipids Health Dis 2012;11(114):1-9.

16. Moroti C, Magri LFS, Costa MDR, Cavalini DCU, Sivleri $\mathrm{K}$. Effect of the consumption of a new symbiotic shake on glycemia and cholesterol levels in elderly people with type 2 diabetes mellitus. Lipids Health Dis 2012;11(29):1-8.

17. World Health Organization (WHO). General Guidelines for Metodologies on Research and Evaluation of Traditional Medicine. Geneva : WHO; 2001. p.1-71
18. Muflikhatur S, Murwani H. Perbedaan pengaruh antara ekstrak dan rebusan daun salam (Eugenia polyantha) dalam pencegahan peningkatan kadar kolesterol total pada tikus Sprague Dawley. Journal of Nutrition College 2014;3(1):142-9.

19. Ratnawati H, Widowati W. Anticholesterol Activity of Velvet Bean (Mucuna Pruriens L.) towards Hypercholesterolemic Rats. Sains Malaysiana. 2011; 40(4): 317-21.

20. Nikjooy S, Hashemi S. Study The Possibility of Producing Symbiotic Yogurt Containing Lactobacillus casei and Wild Thyme Extract. International Journal of Agriculture and Crop Sciences 2015; 8(1): 61-7.

21. Yuniastuti A. Pengaruh Pemberian Susu Fermentasi Lactobacillus casei Strain Shirota Terhadap Perubahan Kadar Fraksi Lipid Serum Tikus Hiperkolesterolemia. Jurnal of Nutrition College. 2004; 1-96.

22. Ratnawati H, Widowati W. Anticholesterol Activity of Velvet Bean (Mucuna Pruriens L.) towards Hypercholesterolemic Rats. Sains Malaysiana 2011; 40(4): 317-21.

23. Crescenzo R, Bianco F, Coppola P, Mazzoli A, Tussellino M, Carotenuto R, et al. Fructose Supplementation Worsens The Deleterious Effects of Short-Term High-Fat Feeding on Hepatic Steatosis and Lipid Metabolism in Adult Rats. Exp Physiol 2014:99(9): 1203-13.

24. Tsalissavrina I, Wahono D, Handayani D. Pengaruh Pemberian Diet Tinggi Karbohidrat dibandingkan Diet Tinggi Lemak Terhadap Kadar Trigliserida dan HDL Darah pada Rattus novergicus galur wistar. Ilmu Gizi Kesehatan Fakultas Kedokteran Universitas Brawijaya. Jurnal Kedokteran Brawijaya. 2006; 22(2): 80-9.

25. Prahastuti S. Konsumsi Fruktosa Berlebihan dapat Berdampak Buruk bagi Kesehatan Manusia. JKM 2011;10(2): 173-89.

26. Ramasamy K, Shafawi ZM, Mani V, Wan HY, Majeed ABA. Hypocholesterolaemic Effects of Probiotics. Intech. 2012; 163-80.

27. Lye HS, Rusul G, Liong MT. Removal of Cholesterol by Lactobacilli via Incorporation of and Conversion to Coprostanol. J Dairy Sci. 2010; 93: 1383-92.

28. Khamisy AESE. Effect of Bifidobacterium and Lactobacillus acidophilus in Diabetic Rats. In The 5th Arab and 2nd International: Annual Scientific Conference. Egypt: Faculty Specific Education - Mansoura University. 2010; 2425-39.

29. Scavuzzi BM, Henrique FC, Miglioranza LHS, Simão ANC, Dichi I. Impact of Prebiotics, Probiotics and Synbiotics on Components of the Metabolic Syndrome. Ann Nutr Disord \& Ther. 2014;1(2):1-13.

30. Aguilar HM, Baez DA, Estrada MJ, Guererro GM, Bautista RJH, Alarcón-Aguilar FJ, et al. Effect of 
Zana Fitriana Octavia, dkk: Pengaruh pemberian yogurt sinbiotik tepung pisang tanduk terhadap profil lipid tikus sindrom metabolik

fructooligosaccharides fraction from Psacalium decompositum on inflammation and dyslipidemia in rats with fructose-induced obesity. Nutrients 2014;6(2):591604.

31. McRae MP. Vitamin C supplementation lowers serum low-density lipoprotein cholesterol and triglycerides: a meta-analysis of 13 randomized controlled trials. Journal of Chiropractic Medicine 2008; 7: 48-58.

32. Kasolo JN, Bimenya GS, Ojok L, Ochieng J, Ogwal-Okeng JW. Phytochemicals and Uses of Moringa oleifera Leaves in Ugandan Rural Communities. Journal of Medicinal Plants Research 2010; 4(9): 753-57. 